\title{
Savaş veya Doğal Afet Sonrasında Çocuk veya Ergenlere Uygulanan Okul Bazlı Müdahalelerin Ruh Sağlığı Semptomlarına Etkililiği Üzerine Bir Sistematik Derleme
}

\author{
Rüveyda Çal $^{1}$
}

\begin{abstract}
$\ddot{\mathbf{O} z}$
Dünya üzerinde azımsanamayacak sayıda çocuk ve ergen, savaşlar ve doğal afetlerden etkilenmekte ve bu sayı gün geçtikçe artmaktadır. Öte yandan, olağan düzeni sarsan bu durumlar, çocuk ve ergenlerin travmatik olaylara maruz kalma olasılıklarını ve dolayısıyla ciddi ruh sağlığı problemleri yaşama risklerini artırmaktadır. Okullar, özellikle bu kriz durumlarından sonra ruh sağlı̆̆ hizmetlerinin aktarılmasını sağlayan kurumların başında geldikleri halde, literatürde bu hizmetlerin etkililiği konusunda yeterince çalışma bulunmamaktadır. Bu derlemede, okul bazlı müdahalelerin, savaş veya doğal afet kaynaklı travmaya maruz kalmış çocuk veya ergenlerdeki travma sonrası stres bozukluğu (TSSB), depresyon ve anksiyete semptomları üzerinde etkililiği araştırılmıştır. Sistematik araştırma PsychInfo, PubMEd, Scopus ve PTSDPubs veri tabanları üzerinden "okul-bazlı müdahaleler", "savaş", "doğal afet" ve "travma" anahtar kelimelerini kullanarak gerçekleştirilmiştir. Erişilen çalışmaların kalite değerlendirmesi "Etkili Halk Sağlığı Projesi”" nitel çalışmalar için kalite değerlendirme aracı ile yapılmıştır. Yeterli kalitede bulunan çalışmalar içerisinden dahil etme ve hariç tutma kriterlerine uyan 12 çalışma seçilmiştir. Çalışmaların çoğu TSSB, depresyon ve anksiyete semptomlarında düşüşler olduğunu gösterirken, en başarılı sonuçların doğal afet kaynaklı travma için yapılan müdahaleler sonucunda TSSB semptomlarında alındığı gözlemlenmiştir. Uygulayıcıların öğretmenler olduğu ve diğerlerine göre daha uzun süren müdahalelerin üç semptom türünde de en başarılı müdahaleler olduğu görülmüştür. Bu çalışma sonucunda, savaş ve doğal afetlerden sonra uzun süren ve öğretmenler tarafından aktarılan okul bazlı müdahalelere öncelik verilmesinin TSSB, depresyon ve anksiyete semptomlarını iyileştirmede daha etkili olacağı sonucuna varılmıştır.
\end{abstract}

Anahtar Kelimeler

Okul bazlı müdahaleler $•$ Savaş $•$ Doğal afet $\bullet$ TSSB $\bullet$ Depresyon $•$ Anksiyete

1 Queen Mary University of London, Wolfson Institute, EC1M 6AX, Barbican/Londra. Eposta: HYPERLINK "mailto:h.r.cal@hss17.qmul.ac.uk" h.r.cal@hss17.qmul.ac.uk 


\title{
A Systematic Review of the Effectiveness of School-based Interventions for Mental Health Symptoms of Children or Adolescents After War or Natural Disaster
}

\author{
Rüveyda Çal
}

\begin{abstract}
Worldwide, wars and natural disasters affect a considerable number of children and adolescents and this number is constantly increasing. On the other hand, such extraordinary situations cause children and adolescents to be exposed to traumatic events and pave the way for serious mental health disorders. Although schools are one of the main institutions in transferring mental health services, especially after these crisis situations, studies on the effectiveness of school-based interventions remain insufficient in the literature. This review examined the efficacy of schoolbased interventions for post-traumatic stress disorder (PTSD), depression and anxiety symptoms of war or natural disaster exposed children or adolescents. The systematic research was conducted in four databases, PsychInfo, PubMED, Scopus and PTSDPubs, using key subject terms "schoolbased interventions", "war", "natural disaster" and "trauma”. Identified papers were assessed using Effective Public Health Practice Project (EPHPP) quality assessment tool for quantitative studies. A total of 12 studies were selected that met the inclusion and exclusion criteria. While most studies have shown declines in PTSD, depression and anxiety symptoms, the most successful results have been observed in PTSD symptoms following interventions for natural disaster-induced trauma. Interventions in which practitioners were teachers and lasted longer than others yielded the most successful results in all three types of symptoms. The study concluded that prioritizing schoolbased interventions that persist long and delivered by teachers after wars or natural disasters may be more effective in improving PTSD, depression and anxiety symptoms of children or adolescents.
\end{abstract}

\section{Key Words}

School-based interventions $\bullet$ War $\bullet$ Natural Disaster $・$ PTSD $\bullet$ Depression $•$ Anxiety

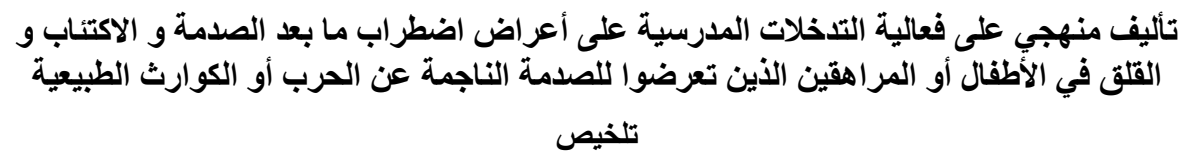

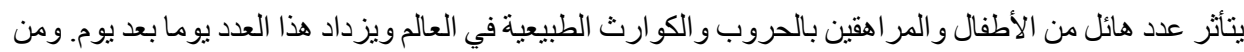

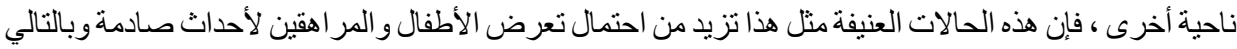

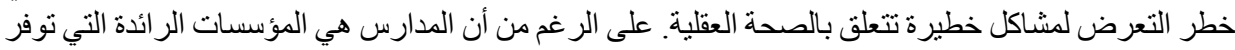

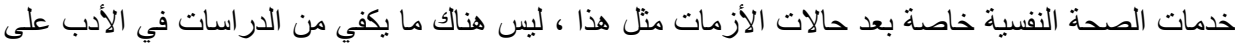

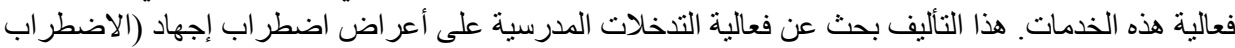

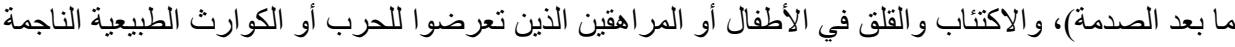

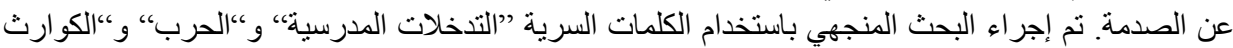

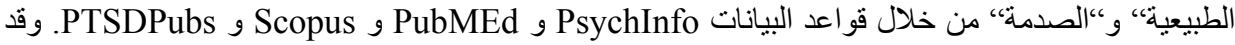

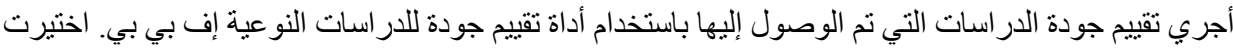

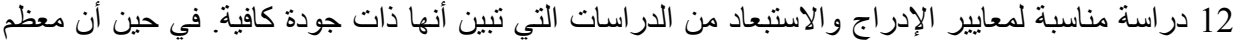

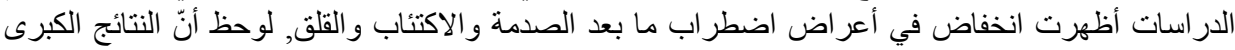



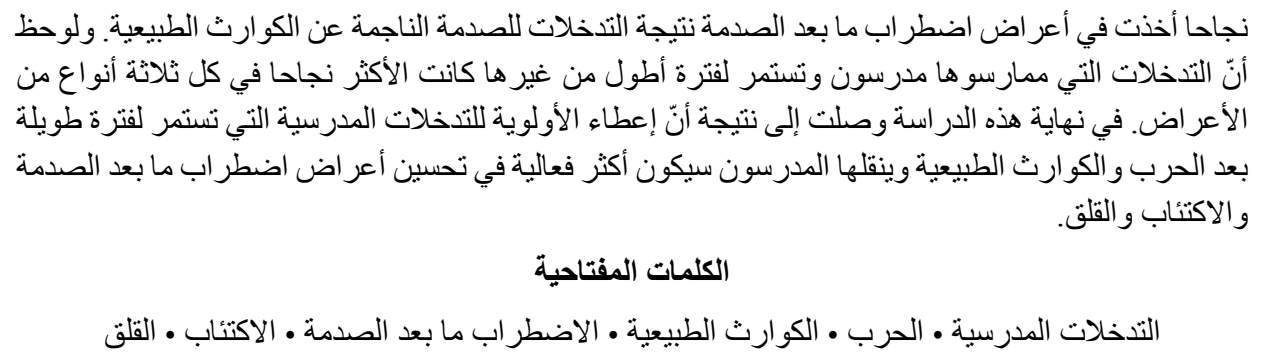

\section{Giriş}

Travma, tek bir olaydan, birkaç olaydan veya kronik hadiselerden kaynaklanabilen; birey tarafindan fiziksel veya duygusal olarak hasar verici olarak tecrübe edilen durumlardır. Kişinin işlevselliği ve zihinsel, fiziksel, sosyal duygusal ve manevi iyi oluşu üzerinde kalıcı zararlı etkiler bırakır (Substance Abuse and Mental Health Services Administration, 2014). Travmaya maruz kalma kavramı farklı türlerde tecrübeleri kapsar. Bu tecrübeler kişi veya kişiler tarafından işlenmiş olan, savaş ve çatışmalar gibi insan kaynaklı travmalar veya depremler veya kasırgalar gibi doğa kaynaklı olanlar olabilir. Travma pek çok çeşitte ve varyasyonda yaşanabilse de, her travmatik olay yoğun korkuya, dehşete, çaresizlik hissine sebep olması ve kişinin başa çıkma becerilerine zarar vermesi bakımından benzer etkilere sahiptir (Raviv ve Jaycox, 2015).

UNESCO (2016) tarafından yapılan tahminlere göre, dünya çapında her dört çocuktan biri çatışmalardan ve afetlerden etkilenen bölgelerde yaşamaktadır. Afetler ve savaşlar, sosyal normların ve altyapıların çöküntüye uğradığı ve temel hizmetlere erişimin zorlaştığı, sağlık ve iyi oluş konusunda derin riskler barındıran durumlardır (Laor, Wolmer, Spirman, ve Wierner, 2003). Bu bölgelerde yaşayan çocuk ve ergenlerin ise çeşitli travmatik olaylara maruz kalma riskleri artmaktadır. Örneğin, çocuklar, ölü bedenler veya vücut parçaları görerek, birçok insanın aynı anda öldürülmesine şahit olarak veya evlerin tahrip edildiğini ve yağmalandığını görerek savaş travması yaşayabilirler (Dyregrov, Gupta, Gjestad, ve Mukanoheli, 2000; Yule ve Smith, 2000). Benzer şekilde doğal afete maruz kalmış çocuklar ve ergenler etrafta ölü bedenler görerek, afet sonrası yağmalamaya tanık olarak veya kendilerinin veya başkalarının yaralanmasıyla travmatize olabilirler (Garfin ve ark., 2014). İstatistiksel olarak örnek vermek gerekirse, süregelen savaş şiddetinin içinde yaşayan 83 Filistinli çocukla çalışan Barron, Abdallah ve Smith (2013), bu çocuklardan \%83'ünün yakın bombalamaya şahit olduğunu, \% 78.3'ünün ölü bir bedenle karşılaştığını, \% 77.1'inin aile üyelerinden birinin yaralandığını ve \%74'ünün birinin öldürüldüğünü gördügünü ortaya koymuştur. Diğer taraftan, tsunamiye maruz kalmış 166 çocukla yapılan çalışma çocukların \%82'sinin tsunami anında orada bulunduğunu ve yaralandığını, \%66.7'sinin yakından tanıdıkları birinin öldüğünü raporlamıştır (Gelkopf ve Berger, 2009).

Yakın tarihli bir sistematik derleme ise savaş bölgelerinde yaşayan ve toplumun geri kalanıyla kıyaslandığında yüksek seviyelerde travmaya maruz kalmış olan 
çocuk ve ergenlerde travma sonrası stres bozukluğu (TSSB), depresyon, anksiyete ve hiperaktivite gibi zihinsel, davranışsal ve duygusal problemlerin arttığını göstermiştir (Dimitry, 2012). Doğal afete maruz kalmış çocuklarla yapılmış çalışmalar, doğal afete maruz kalmanın da travma sonrası stres, depresyon ve anksiyete gibi psikolojik semptomların yaşanma riskini artırdığını ortaya koymuştur (Liu ve ark., 2011; Osofsky, Osofsky, Kronenberg, Brennan ve Hansel, 2009; Roussos ve ark., 2005).

Savaş ve doğal afet sonrasında yapılmış çalışmalarda en çok incelenen ruhsal bozukluğun travma sonrası stres bozukluğu olduğu görülmektedir. Travma sonrası stres bozukluğu (TSSB), travmatik bir olayın neticesinde görülen, olay hakkındaki bazı detayların gayri ihtiyari olarak hatırlanması, aşırı uyarılma, kaçınma ve duygusal hissizleşme ile karakterize bir ruhsal bozukluktur (American Psychiatric Association (APA), 2000). Filistin'deki savaşa maruz kalmış ve mülteci kamplarında yaşayan ergenlerdeki TSSB oranı \%68.9 olarak bulunmuştur (Elbedour, Onwuegbuzie, Ghannam, Whitcome ve Hein, 2007). Filistin'deki süregelen savaş şiddetinin içinde yaşayan çocuk ve ergenlerle yapılan bir başka çalışmada ise TSSB prevalansı \%70.1 olarak kaydedilmiştir (Thabet, Tawahina, El Sarraj ve Vostanis, 2008). Ayrıca bu çalışma, maruz kalınan travmatik olay sayısının TSSB semptom şiddetiyle ilişkili olduğunu bulmuştur. Bu veri başka ülkelerden başka bulgularla da desteklenmiştir. Örneğin, Macksoud ve Aber'in (2016) savaşa maruz kalmış 224 Lübnanlı çocukla yapılan araştırması daha çok sayıda travmaya maruz kalan çocukların, diğer çocuklara göre daha fazla TSSB semptomu gösterdiğini ortaya koymuştur. Katılımcıların doğal afete maruz kalmış kişiler olduğu araştırmalar da benzer sonuçlara ulaşmıştır. Şili depremine maruz kalmış 119 ilkokul öğrencisiyle yapılmış çalışmaya göre (Garfin ve ark., 2014), çocukların \%55.56'sında DSM-IV kriterlerine göre muhtemel TSSB bulunuyordu. Ve geri kalan pek çok çocuk da travma sonrası stres (TSS) belirtileri taşımaktaydı. Yine bu çalışmaya göre, belli travma tipleri TSS semptomatolojisi ile ilişkiliydi. Bu travma tipleri ise; deprem kaynaklı yaralamayı deneyimlemiş olmak, ölü bir beden görmüş olmak ve tanıdık birinin yaralanmasıydı. Buradan hareketle, savaş ve doğal afetlerden kaynaklı yaşanan travmaların sayısı ve tiplerinin TSSB seviyesi ile yakından ilişkili olduğu savunulabilir.

Depresyon, savaş ve doğal afet sonrası yapılan çalışmalarda en çok raporlanan ruh sağlığ1 problemlerinden bir diğeridir. Depresyon, üzgün, kasvetli ve kötümser bir ruh hali olarak tanımlanabilecek; normalde zevk alınan şeylerden artık zevk alınmaması, uykusuzluk, kilo kaybı, suçluluk ve değersizlik hissi ve konsantrasyon kaybı ile karakterize bir rahatsızlıktır (Colman, 2015). Bakım verenlerinden uzakta yaşayan ve evleri yıkılmış Bosnalı çocukların yaşadığı savaş travmasının depresyon ile ilişkili olduğu bulunmuştur. Bu örneklemin \%43'ü depresyon belirtileri göstermiştir (Yule ve Smith, 2000). Bu katılımcıların içinde yaşı büyük olan çocuklar ve daha fazla sayıda travmaya maruz kalmış çocukların daha yüksek seviyelerde depresyon yaşamakta oldukları görülmüştür. Bir başka çalışmada, Amerika'ya taşınmış ve bir yıldır orada olan Bosnalı ergenlerde depresyon prevalansı \%17 olarak belirlenmiştir (Weine ve ark., 1995). Orta şiddette bir depremden sonra yapılan araştırma sonucunda çocuk ve 
ergenlerdeki depresyon sıklığı \%13 olarak hesaplanmıştır (Roussos ve ark., 2005). Yine bu çalışmada depresyon seviyesi yüksek TSSB seviyesi ile ilişkili bulunmuştur. Bir başka çalışma ağır şekilde kasırgadan etkilenmiş şehirlerde yaşayan çocuk ve ergenlerde şiddetli depresyon seviyeleri görüldüğünü bulmuştur (Goenjian ve ark., 2001). Bu çalışma, yüksek TSSB seviyesinin ve aile üyelerinden birinin ölümünün depresyonun şiddetiyle ilişkili olduğu sonucuna varmıştır. Burada görüldüğü gibi, savaş ve doğal afet travmaları depresyonda önemli artışlara sebep olmaktadır. Bununla birlikte, bu artışların travmanın şiddetinden, yaş gibi demografik faktörlerden ve başka ruhsal bozuklukların varlığından yakından etkilendiği söylenebilir.

Bir başka yaygın semptom olan anksiyete, varsayılan bir tehlikeden, talihsizlikten veya başarısızlıktan kaynaklanan rahatsızlık halidir. Hoşnutsuzluk hali ve somatik semptomlarla kendini gösterir (Colman, 2015). Şiddetli savaşın ortasında yaşamış ve şimdi mülteci kamplarında olan ergenlerde anksiyete oranı \%94.9 olarak saptanmıştır (Elbedour ve ark., 2007). Bu çalışmanın da gözlemlediğine göre TSSB teşhisi koyulan çocuk ve ergenlerde anksiyete görülme riski artmaktadır. Boylamsal bir çalışma, şiddetli deprem yaşamış çocukların \%22.7'sinin yapılan ilk değerlendirmede, \%23.3'ünün de depremden 6 ay sonra anksiyete semptomları gösterdiğini ortaya koymuştur (Liu ve ark., 2011). Bu çalışma ayrıca yaşı büyük olan çocukların daha yüksek seviyede anksiyete yaşadığını raporlamıştır. Bu örneklerden hareketle, savaş ve doğal afet olaylarının çocuk ve ergenlerde belirgin şekilde anksiyete seviyesini artırdığı, bu artışın TSSB ile beraber olabileceği ve anksiyetenin yaşı büyük olan çocuk ve ergenlerde görülme riskinin daha yüksek olabileceği sonucuna varılabilir.

Savaşlar ve doğal afetler, çocuk ve ergenlerin pek çok farklı psikolojik ve davranışsal problem yaşama risklerini artırsa da, TSSB, depresyon ve anksiyete bu durumlardan sonra en çok gözlemlenen ruhsal bozukluklardır (Attanayake ve ark., 2009; Norris ve ark., 2002). Bu sebeple, bu derleme, savaş veya doğal afet kaynaklı oluşmuş TSSB, depresyon ve anksiyete semptomlarına yönelik okul bazlı müdahaleler ile sinırlı olacaktır.

\section{Okul Bazlı Müdahaleler}

Araştırmalara göre çocuk ve ergenlerin çoğu travmatik olaylardan sonra iyileşip olağan işlevselliklerine geri dönebilmektedir (Bonanno ve Mancini, 2008). Ancak yukarıda da bahsedildiği üzere, savaş ve doğal afetlerden sonra yaşanan ruh sağlığı problemlerinin sıklığı ruh sağlığı hizmetlerine olan ihtiyacı artırmaktadır. Bu durumlardan sonra, çocuk ve ergenlerin psikiyatrik ve sosyal-duygusal ihtiyaçlarını karşılamak için verilen ruh sağlığı hizmetleri; psikoterapi, rehberlik, travma odaklı bilişsel davranışçı terapi (Hanson ve Jobe-shields, 2017), kisa travma/yas odaklı psikoterapi, grup terapisi, oyun terapisi, aile üyelerinin ve çocuğun psikoeğitimi ve psikofarmakolojiyi (Kar, 2009) içerir. 
Okul bazlı müdahaleler, ruh sağlığı hizmetlerine ulaşmada ortaya çıkan engelleri gidermek ve bu hizmetlerin koordinasyonunu artırmak için geliştirilen önleme çalışmaları veya müdahale programlarıdır ve okul danışmanı tarafından verilen en küçük destekten kapsamlı ve entegre edilmiş tanı ve tedavi programlarına kadar geniş bir çerçeveyi kapsar (American Academy of Pediatrics, 2004). Amerikan Academy of Pediatrics (2004), okul bazlı müdahalelerin farklı formlarını üç katmanlı bir modelle açıklamaktadır. $\mathrm{Bu}$ modelin ilk aşaması her okulda her öğrenciye uygulanabilecek aktiviteleri kapsayan önleyici ruh sağlığı programlarından oluşmaktadır. Bu aktiviteler genellikle risk faktörlerini azaltmayı ve çocuk ve ergenlere sağlıklı bir gelişim gösterebilmeleri için ihtiyaç duydukları desteği sağlamayı amaçlar. İkinci aşamada yer alan hedef odaklı ruh sağlığı hizmetleri, bir ya da daha fazla ruhsal problemi olan ve sosyal ve akademik çalışmalara katılabilen öğrenciler için uygulanan grup veya bireysel terapileri içermektedir. Son aşama ise ciddi bir ruhsal bozukluk tanısı konmuş öğrenciler için uygulanan müdahalelerdir; bu müdahaleler özel eğitim servislerinden, bireysel terapi ve aile terapisinden, hastaneden, okuldan ve sosyal hizmetlerden gelen profesyonellerden oluşan disiplinler arası bir ekip oluşturmayı gerektirir.

Büyük olasılıkla travmatik olay hakkında konuşmaktan ve dolayısıyla olayı hatırlamaktan kaçındıkları için (Raviv ve Jaycox, 2015), travmaya maruz kalmış çocuk ve ergenler böyle bir tecrübesi olmayan yaşıtlarına göre ruh sağlığı hizmetlerine daha az başvurmaktadırlar (Guterman, Hahm ve Cameron, 2002). Ayrıca, çocuk ve ergenler psikolojik rahatsızlıklar yaşadıklarında, yaşlarından ve gelişim düzeylerinden kaynaklı bilgi eksiklikleri onların yardım arayışına girme becerilerini kısıtlayabilmektedir (Silverman ve La Greca, 2004). Çocuklar kendileri için yardım arayışına giremediklerinde ise ruh sağlığı hizmetlerine olan güven eksikliğinden veya finansal yetersizliklerden dolayı aileler de çocuklarına destek olmakta eksik kalabilmektedir (Raviv ve Jaycox, 2015). Bu sebeplerin yanında, özellikle savaş ve doğal afet durumlarında, çocuk ve ergenlerin psikolojik ve duygusal ihtiyaçları, temel sağlık hizmetlerinin çöküntüye uğramasından ve bakım veren yetişkinlerin de olay kaynaklı baş etme problemleri yaşamasından dolayı karşılanmayabilmektedir (Silverman ve La Greca, 2004). Kriz durumlarında yeterli fiziksel, sosyal ve duygusal destek sağlanamaması ise ruh sağlığ problemlerini beraberinde getirir (Fu ve Underwood., 2015).

Okullar, özellikle kriz durumlarında, çocuk ve ergenlere ruh sağlığı hizmetlerinin aktarılmasında en önemli kurumlardan biri olma özelliğini taşımaktadır (Jaycox, Morse, Tanielian ve Stein, 2006). Okul, çocuk için aileden sonra en önemli sosyal bileşenlerden biri olarak, toplum fiziksel ve duygusal olarak yaralayıcı olduğunda güvenlik ve emniyet hissini sağlayan önemli bir ortam haline gelmektedir (Kilmer, Gil-Rivas ve MacDonald, 2010). Diğer yandan, psikolojik müdahaleler öğrencilerin tanıdığı okul ruh sağlığı uzmanları tarafindan alışılmış okul ortamında aktarıldığında, öğrencilerin ruh sağlığı hizmetlerine karşı olan ön yargıları ve isteksizlikleri azaltılabilir (Sullivan 
ve Simonson, 2016). Bu şekilde öğrencilerin düzenli katılımının sağlanmasının yanında, bu hizmetler okullarda öğrencilere ücretsiz olarak ulaştırılabilir (President, Commission, \& January, 2003) ve böylece ailelerin çocuklarına destek sağlaması kolaylaştırılabilir. Okul, kendisi için yardım aramakta zorlanan gençler için de oldukça avantajlı olabilmektedir. Okul ortamında, ruh sağlığı ve akademik ve sosyal beceriler üzerine; ebeveynler, öğretmenler ve okul psikologlarının farklı perspektiflerinden yapılan değerlendirmelerle, çocuk ve ergenin probleminin daha hızlı ve daha bütüncül bir şekilde anlaşılması sağlanabilmektedir (Reddy, 2009).

Okullarda travma için uygulanan bilişsel davranışçı müdahale ile klinik bazlı travma odaklı davranışçı terapiyi karşılaştıran bir çalışma, öğrencilerin klinik bazı müdahalede TSSB ve depresyonda daha yüksek semptom düşüşleri gösterdiğini kaydetse de; bu çalışmada okul bazlı müdahaleye katılım oranının çok daha yüksek olduğu görülmüştür (Jaycox ve ark., 2010). Savaşa maruz kalmış çocuk ve ergenlere uygulanan okul bazlı müdahalelerle bekleme listelerini karşılaştıran çalışmalar; müdahale uygulanan gruplarda, bekleme listeleriyle karşılaştırıldıklarında TSSB ve anksiyete semptomlarında anlamlı düşüşler olduğunu gözlemlemiştir (Baum ve ark., 2013; Berger, Gelkopf ve Heineberg, 2012; Gormez ve ark., 2017). Depresyon semptomlarında ise, savaş travması yaşamış çocuklara uygulanan okul bazlı müdahalelerin, bekleme listeleriyle karşılaştırıldıklarında benzer şekilde anlamlı ve yüksek semptom düşüşlerini sağladıkları gözlemlenmiştir (Gelkopf ve Berger, 2009).

Klinik bazlı müdahaleler, okul bazlı müdahalelerden daha yüksek semptom düşüşlerine sebep olsalar da okul bazlı müdahaleler, ruh sağlı̆̆ hizmetlerine erişimi kolaylaştırmaları sebebiyle çocuk ve ergenlere ihtiyaç duydukları desteği sağlamak için tercih edilen metot haline gelebilir. Okul bazlı müdahalelerin savaş ve doğal afet kaynaklı yaşanan travmalardan sonra önemli semptom düşüşlerine sebep olduğunu kanıtlayan çalışmalar da olduğu göz önünde bulundurulduğunda, okul bazlı müdahalelerin bu gibi kriz durumlarında oldukça gerekli olduğu savunulabilir.

Yukarıda da bahsedildiği gibi, okul bazlı müdahaleler, benzer şekilde travmatik olay yaşama riskini artıran ve benzer ruh sağlığı bozukluklarına sebep olabilen doğal afet ve savaş durumlarından sonra çocuk ve ergenlerin ruh sağlı̆ğ hizmetlerine ulaşmalarını kolaylaştıran önemli müdahale türlerindendir. Yapılan literatür taraması sonucunda, savaş veya doğal afete yönelik okul bazlı müdahaleler ile ilgili çalışmaların son on yılda artış gösterdiği, dolayısıyla araştırmacıların bu alana ilgilerini yeni yeni yönlendirdikleri görülmüştür. Bu çalışma, alanın yeniliği ve yapılmış kanıt bazlı çalışmaların sınırlılığı göz önünde bulundurularak, okul bazlı müdahalelerin savaş veya doğal afet kaynaklı travmadan etkilenmiş çocuk veya ergenlerin travma sonrası stres bozukluğu, depresyon ve anksiyete semptomlarına etkililiğini değerlendiren bir sistematik derleme yürütmeyi ve böylece bu alana katkıda bulunmayı amaçlamaktadır. 


\section{Yöntem}

\section{Sistematik Derleme}

$\mathrm{Bu}$ çalışma bir sistematik derleme olarak yürütülmüştür. Sistematik derleme, iyi tanımlanmış bir araştırma sorusu seçildikten sonra ilgili çalışmaları tespit edilmesi, sentezlenmesi ve bulguların uygun yöntemlerle değerlendirilmesiyle uygulayıcılar ve sağlık otoriteleri için mevcut en iyi kanıtı sağlayan bir yöntemdir (Centre for Reviews \& Dissemination, 2009). Bu çalışmada bulguların sentezi ve değerlendirmesi, istatistiksel verilerin ve ağırlıklı olarak da kelimelerin kullanıldığı anlatı sentezi (Popay ve ark., 2007) kullanılarak yapılmıştır.

\section{Veri tabanları}

Sistematik araştırma, Mayıs-Haziran 2019 tarihleri arasında, dört veri tabanı çerçevesinde, PsychInfo, PubMED, Scopus ve PTSDPubs, gerçekleştirilmiştir. Ayrıca, konuyla alakalı diğer sistematik derlemelerin tespit edilmesi amaciyla Cochrane Sistematik Derlemeler veri tabanı da araştırılmıştır.

\section{Çalışmaların Seçilmesi}

Araştırma sonucunda elde edilen makaleler bu derlemeye özgü olan dahil etme ve hariç tutma kriterlerine göre değerlendirilmiştir. Katılımcılar, müdahaleler, sonuçlar ve araştırma deseni konularında belirgin seçme kriterlerine tabi tutulmuştur. Bu çalışmaya dahil edilen katılımcılar savaşa veya doğal afete maruz kalmış ve halen okula devam etmekte olan çocuk veya ergenlerden oluşmaktadır. Katılımcıların savaş veya doğal afet travmasından farklı travmalar yaşamış (mesela cinsel taciz) olduğu çalışmalar karıştırıcı faktörlerden kaçınabilmek adına dahil edilmemiştir. Travma sonrası stres bozukluğu, söz konusu travmaların ardından görülen tek problem olmadığından ve yapılan çalışmalar savaş ve doğal afetler sonrasında başka şikayetlerin de görüldüğünü kanıtladığından (Gormez et al., 2017; Ooi et al., 2016; Tol et al., 2012); depresyon ve anskiyete teşhisi konulmuş katılımcılar da çalışmaya dahil edilmiştir. Çalışmada değerlendirilen müdahaleler, farklı şekillerde farklı isimlerle uygulanabilen okul bazlı müdahaleleri kapsamaktadır. Müdahaleleri uygulayan kişi veya kişiler konusunda bir kısıtlama getirilmemiştir. Uygulayıcıların öğretmenler olduğu (Gormez et al., 2017), klinisyenler olduğu (Layne et al., 2008), sosyal çalışmacılar olduğu (Salloum \& Overstreet, 2008) veya araştırma görevlileri olduğu çalışmalar (Jordans et al., 2010) dahil edilmiştir. Bu çalışmanın amacının okul bazlı müdahaleleri başka müdahalelerle karşılaştırmak değil, okul bazlı müdahalelerin etkililiğini incelemektir. Dolayısıyla, herhangi bir karşılaştırma grubu kullanılmamıştır. 
Dahil edilen çalışmalar çeşitli ölçme araçları kullandıklarından ve bu araçlar çalışmadan çalışmaya farklılık gösterebildiğinden; araştırma çıktıları TSSB, depresyon ve anksiyete semptomlarında meydana gelen iyileşmeler olacak şekilde belirlenmiştir. Araştırmaya yalnızca nicel çalışmalar dahil edilmiştir.

\section{Araştırma Stratejisi}

Araştırma süreci veri tabanlarına anahtar terimlerin girilmesiyle başlamıştır. Kullanılan araştırma terimleri aşağıda görülebilir; Okul bazlı müdahale veya sınıf bazlı müdahale; Savaş veya çatışma; siyasi şiddet” veya savaş sonrası doğal afet” veya afet; Travma ve Ruh sağliğ

İlk aşamada, tekrar eden araştırma sonuçları kaldırılmıştır. Ardından başlıklar konuyla ilgili olmaları konusunda değerlendirilmiş ve alakalı olmayanlar kaldırılmıştır. Konu dışı başlıklar diğer travma türlerini, klinik bazlı müdahaleleri, İngilizce dışında dilleri ve farklı katılımcı gruplarının (yetişkinler) kullanıldığını belirten ifadeleri içermektedir. Geriye kalan çalışmaların özetleri okunduktan sonra yukarıda açıklanan dahil etme ve hariç tutma kriterlerine uyan çalışmalar tam metin olarak okunmuştur. Tam taramanın ardından 134 çalışma; bazılarına erişim sağlanamamasından, bazılarının okul bazlı bir müdahalenin bir taslağı veya açıklaması olmasından bazılarının ise kalite değerlendirmesinde zayıf olarak değerlendirilmesinden dolayı kaldırılmıştır. Sonuç olarak, 12 çalışma derlemeye dahil edilmiştir.

\section{Kalite Değerlendirmesi}

$\mathrm{Bu}$ sistematik derlemeye yalnızca nicel çalışmalar dahil edilmiştir. Nicel çalışmalar kapsamına farklı araştırma desenleri dahil edilebildiğinden, değerlendirmede tutarlılığı sağlamak için tüm çalışmaların kalite değerlendirmesinde "Etkili Halk Sağlığ 1 Projesi”" [Effective Public Health Project (EPHPP)] kantitatif çalışmalar için kalite değerlendirme aracı (2015) kullanılmıştır. Etkili Halk Sağlı̆̆ı Projesi kalite değerlendirme aracı (2015), seçim yanlılığı, nicel yöntemin uygunluğu, karıştırıcı faktörler, körleme, veri toplama araçlarının uygunluğu, çekilme ve bırakmayı raporlama hakkında 14 sorudan oluşmaktadır. Bu unsurların daha doğru incelenmesi için Etkili Halk Sağlığı Projesi’ne ait bu araca özgü bir sözlük kullanılmıştır. Makalelerin kalitesi hakkında çıkarımlar yapmak için, her bir çalışma kalite değerlendirme aracındaki zayıf, orta ve güçlü kriterlerine göre sınıflandırılmıştır. Söz konusu kalite değerlendirme aracının detaylı uygulaması Tablo 1.'de görülebilir. 


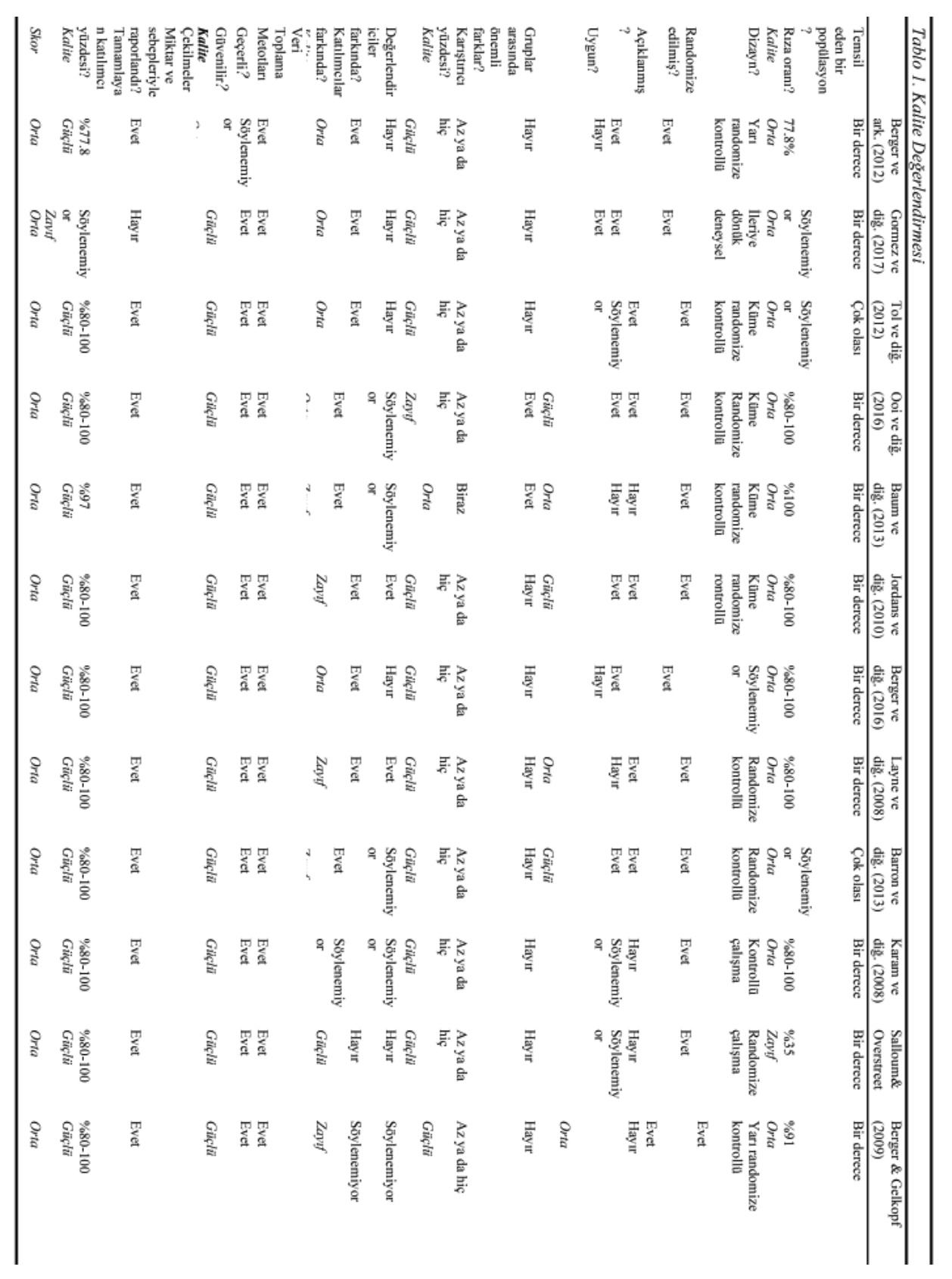

\section{Bulgular}

Veri tabanlarında yapılan sistematik araştırma ve taramanın ardından doğal afet veya savaşa maruz kalmış çocuk veya ergenler için okul bazlı müdahalelere yönelik 12 çalışmaya ulaşılmıştır (Bkz. Şekil 1) Derleme için iki randomize kontrollü çalışma (Barron ve ark., 2013; Layne ve ark., 2008), dört küme randomize kontrollü çalışma 
(Baum ve ark., 2013; Jordans ve ark., 2010; Ooi ve ark., 2016; Tol ve ark., 2012) ve iki yarı randomize kontrollü çalışma (Berger ve ark., 2012; Gelkopf ve Berger, 2009); bir prospektif deneysel çalışma (Gormez ve ark., 2017), bir randomize çalışma (Salloum ve Overstreet, 2008) ve bir nicel çalışma (Berger, Abu-Raiya ve Benatov, 2016) seçilmiştir. Çalışma dizaynları, katılımcı sayıları, yaşları ve cinsiyetleri, travma tiplerini, müdahaleleri, karşılaştırma gruplarını, ölçüm araçlarını ve sonuçları içeren veri özütleme tablosu Tablo 2.'de görülebilir.

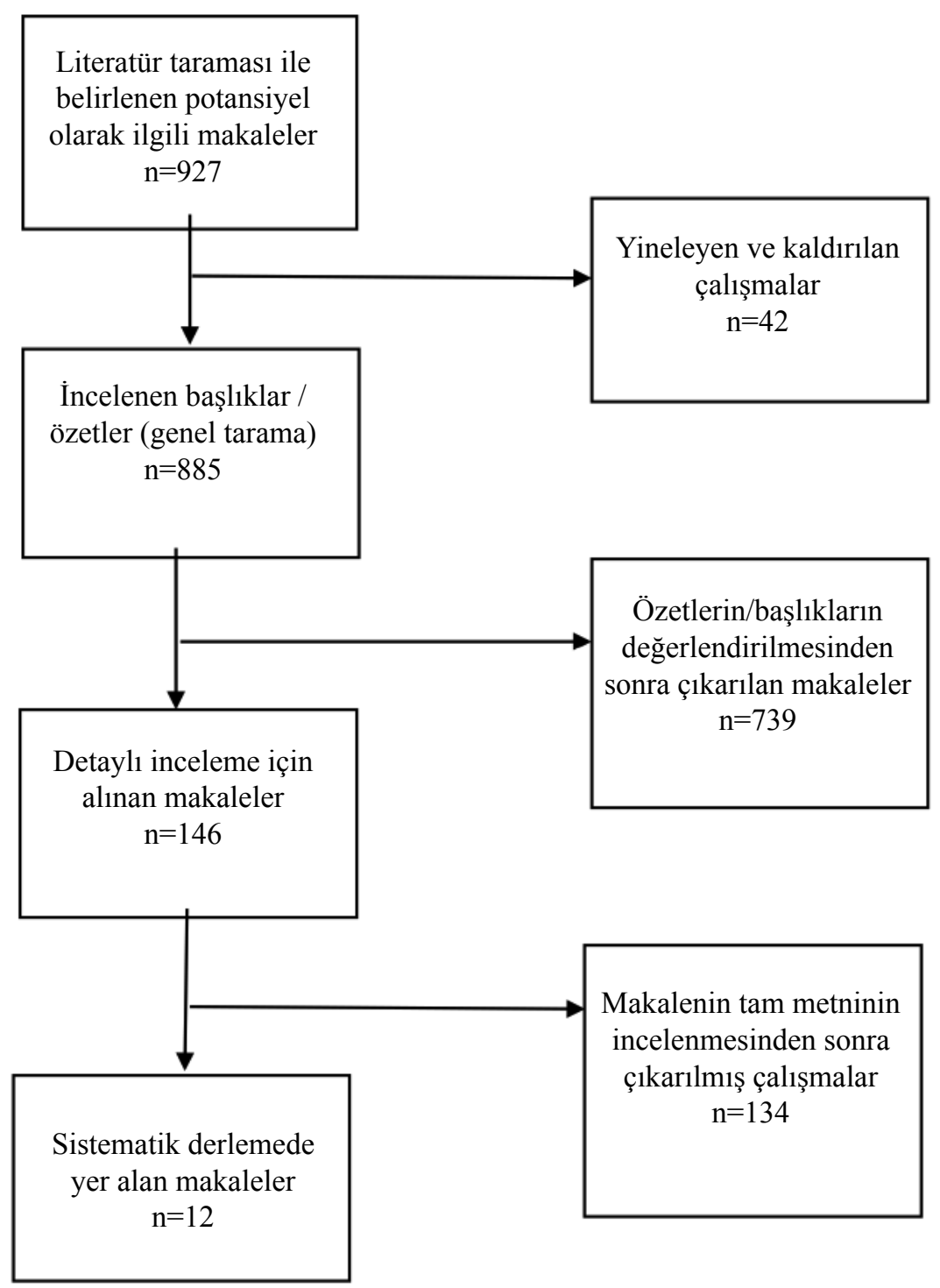

Şekil 1. Sistematik araştırmanın akış şeması 


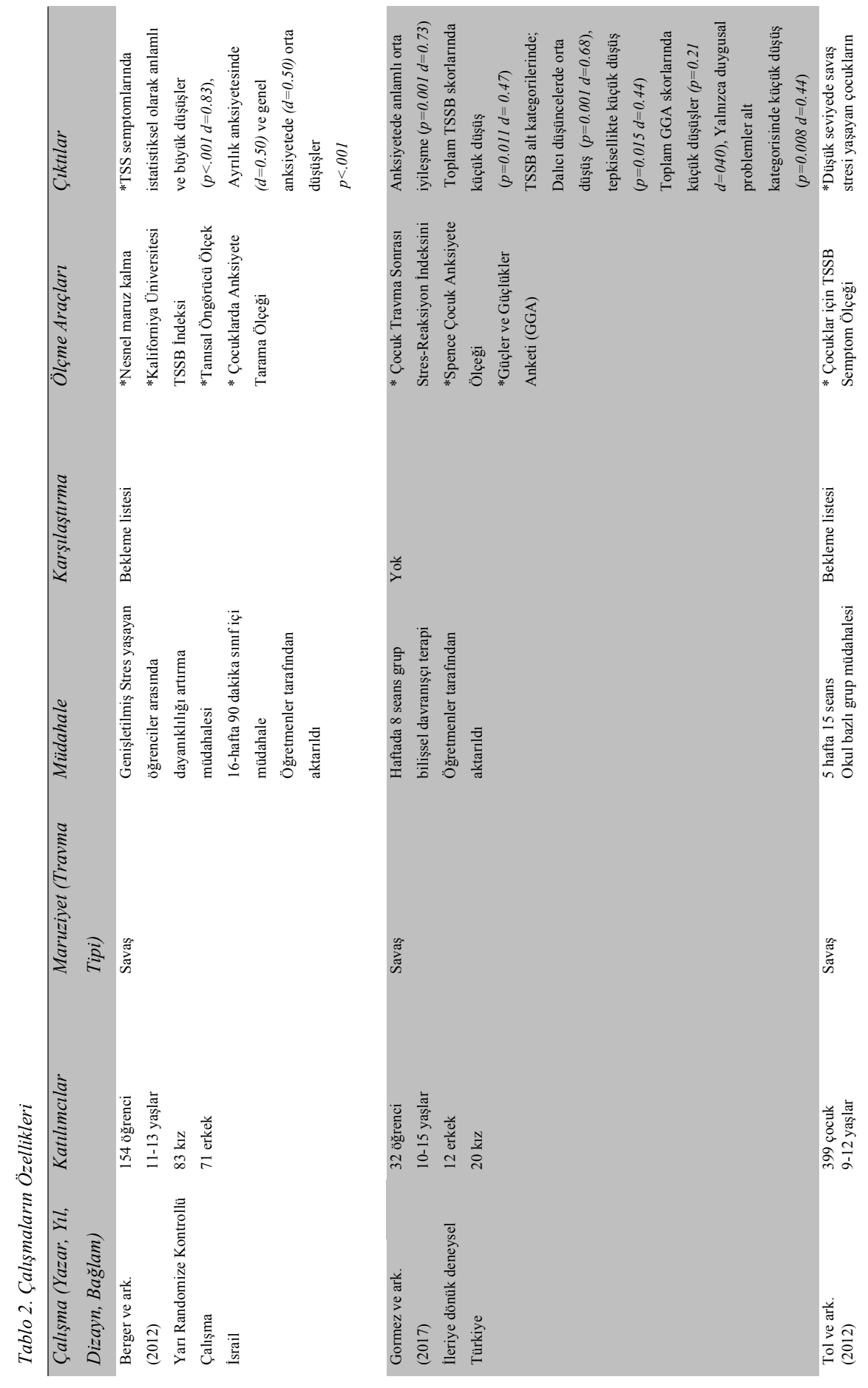



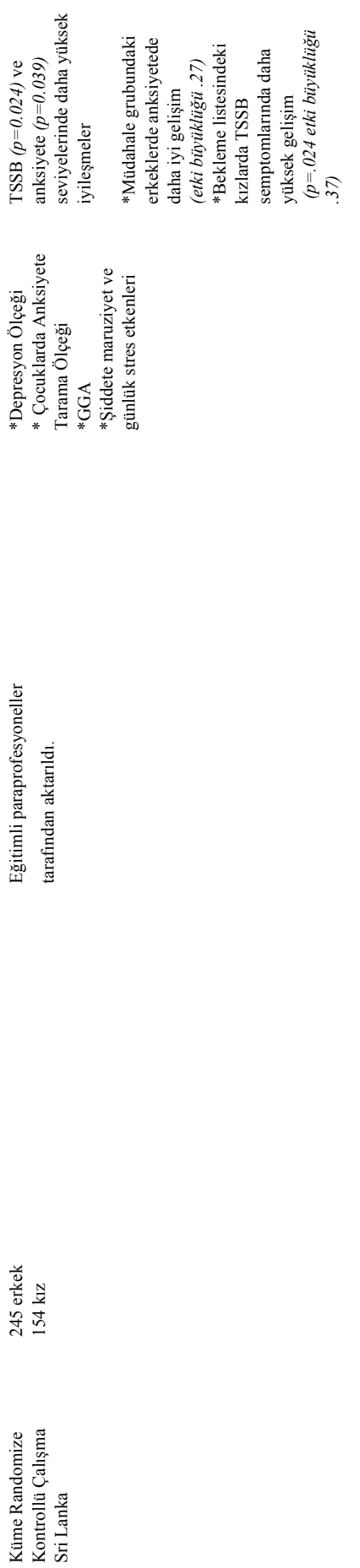
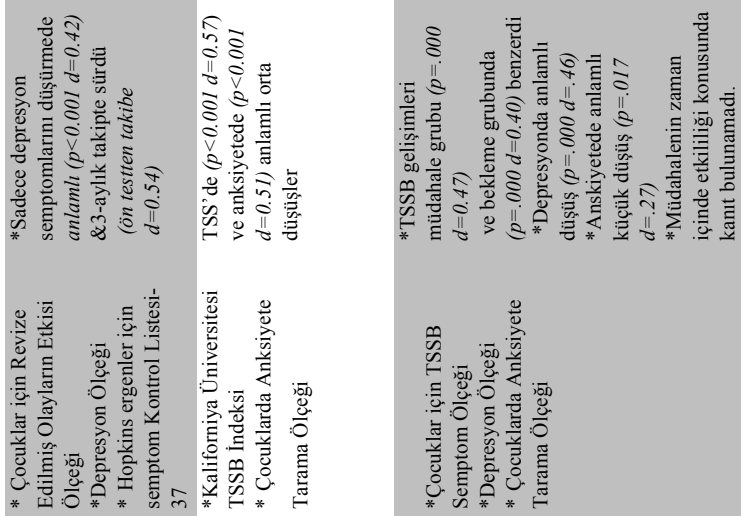

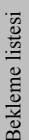
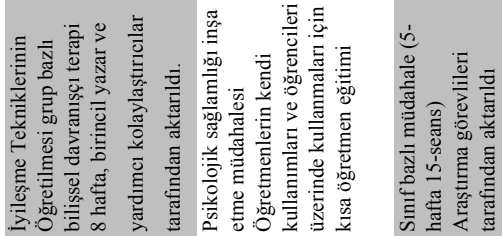

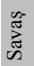
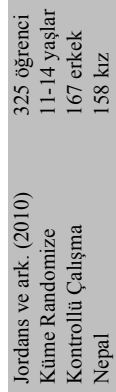


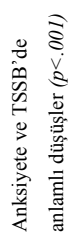
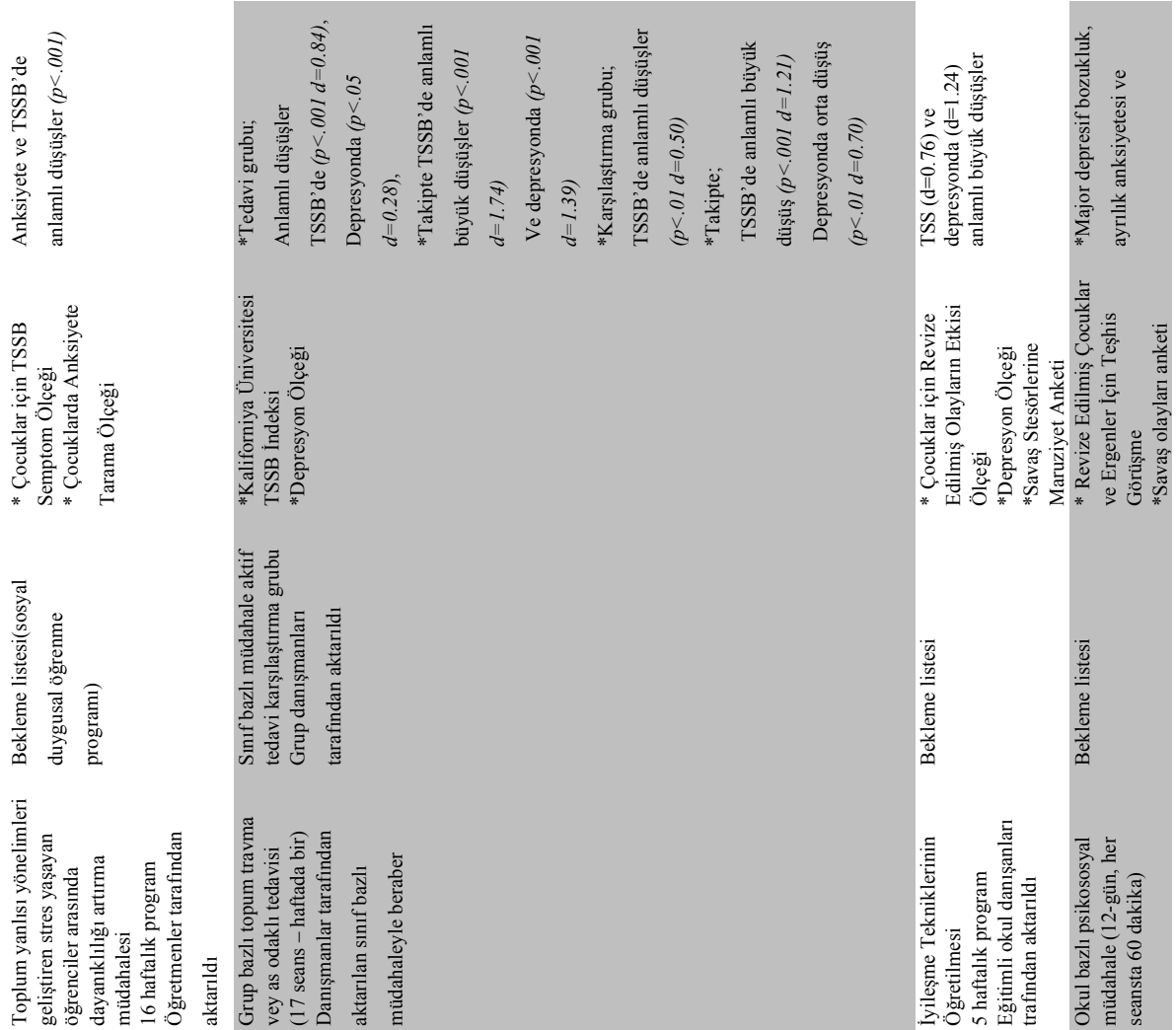

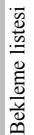

$\overline{0}$
$\frac{0}{0}$
$\frac{0}{0}$
0
$\frac{0}{0}$
$\frac{0}{0}$

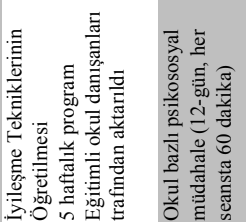

疍

䄓

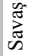

$\stackrel{\infty}{\infty}_{\infty}^{\infty}$

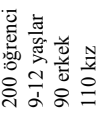
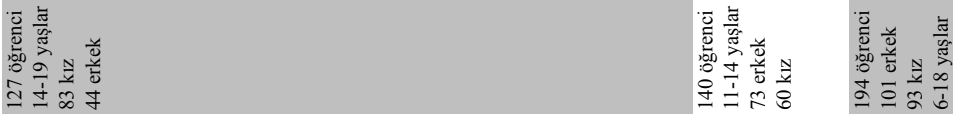

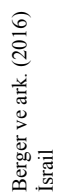
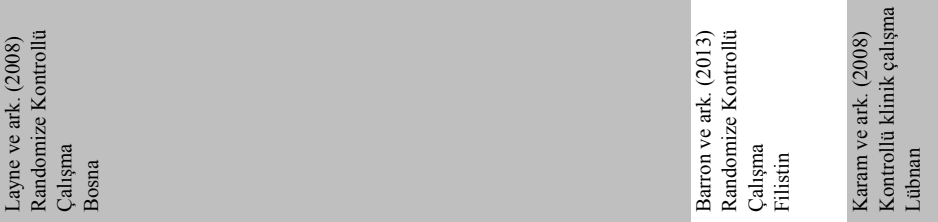


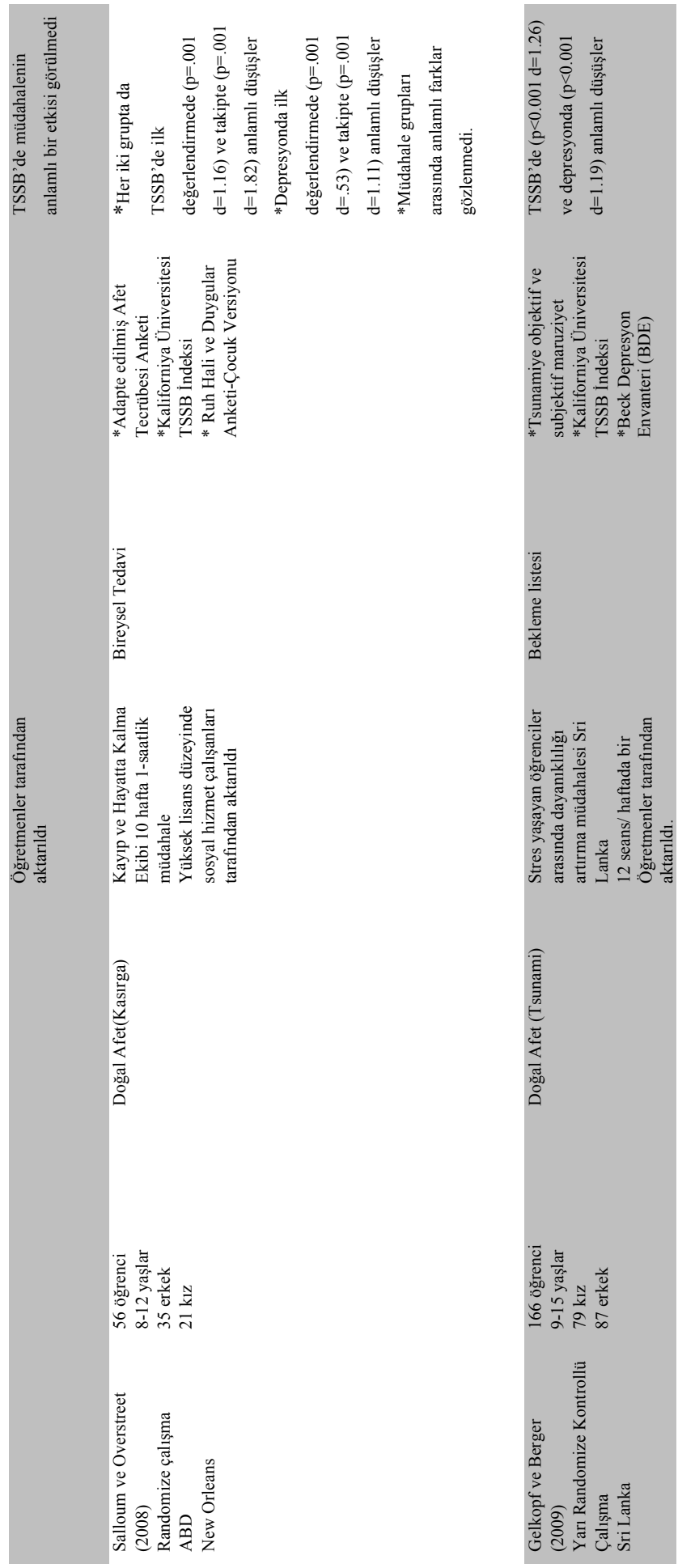




\section{Katılımcı Özellikleri}

Tümüyle çalışmalar, 9 farklı bölgeden toplamda 2,162 katılımcıyı kapsamıştır. Cinsiyet dağılımı neredeyse birbirine denklik göstermiş ve toplam 1030 kız ve 1125 erkek katılmıştır. En küçük katılımcı 6, en büyük katılımcı ise 18 yaşındadır. Katılımcıların 1940’1 savaş sahnelerine maruz kalırken, diğer 222 katılımcı bir doğal afete (kasırga veya tsunami) maruz kalmıştır. Çalışmalar, katılımcıların ruh sağlığı ve iyi oluşları hakkında çeşitli ölçüm araçları kullanmıştır. En sık ölçülen ve rapor edilen tanı TSSB olmuştur. TSSB' den sonra en sık yapılan ölçümler sırasıyla depresyon ve anksiyete için yapılmıştır. En sık kullanılan ölçüm araçları, hepsi beşer kere olmak üzere, Kaliforniya Üniversitesi Travma Sonrası Stres Bozukluğu Tepki İndeksi [University of California at Los Angeles (UCLA) Post Traumatic Stress Disorder (PTSD) Reaction Index], Çocuklarda Anksiyete Tarama Ölçeği [Screen for Child Anxiety Related Emotional Disorders (SCARED)], Güçler ve Güçlükler Anketi (GGA) [Strengths and Difficulties Questionnaire (SDQ)] ve Depresyon Ölçeği [Depression Self Rating Scale (DSRS)] olmuştur.

\section{Müdahale Özellikleri}

Grup BilişselDavranışçıTerapi: İncelenençalışmalardaensıkkullanılanmüdahaleler bilişsel davranışçı müdahaleler olmuştur (7 çalışma tarafından kullanılmıştır). Bilişsel davranışçı teknikler kullanan çalışmaların popülasyonları, kasırgaya maruz kalmış çocuklarla çalışan Salloum ve Overstreet'in (2008) çalışması dışında, savaş travması yaşayan öğrencilerden oluşmaktadır. Bilişsel davranışçı terapi kullanan araştırmaların içinde Tol ve arkadaşları (2012) ve Salloum ve Overstreet'in (2008) çalışmaları, müdahaleleri öğretmenler tarafından verilmeyen ender çalışmalardandır. Görmez ve arkadaşları (2017), savaştan etkilenmiş çocuklar için bilişsel davranışçı bir grup tedavisi kullanmıştır. Çocukları TSSB semptomları hakkında bilgilendirmeyi ve uygun başa çıkma stratejilerini tanıtmayı amaçlayan bu program 8 hafta sürmüştür. Tol ve arkadaşları (2012) ve Karam ve arkadaşları (2008) çalışmalarında bilişsel davranışçı tekniklerle başka tekniklerin beraber kullanıldığı müdahaleler kullanmışlardır. Tol ve arkadaşlarının (2012) 5 haftalık müdahalesi, bilişsel davranışçı tekniklerle yaratıcı ifade öğelerinin bir kombinasyonu şeklindedir ve yaygın ruhsal bozuklukların semptomlarını azaltmayı ve koruyucu faktörleri güçlendirmeyi amaçlamaktadır. $\mathrm{Bu}$ müdahale paraprofesyoneller tarafından uygulanmıştır. Karam ve arkadaşları (2008) ise bilişsel davranışçı tekniklerle stres aşılama eğitimi stratejilerinin kombine edildiği 12 seanslık bir müdahale kullanmıştır.

Salloum ve Overstreet (2008) özellikle ilkokul öğrenciler için geliştirilmiş 10 haftalık Kayıp ve Hayatta Kalma Ekibi [LAST (Loss and Survival Team)] müdahale projesini kullanmıştır. $\mathrm{Bu}$ model öyküsel terapi ve bilişsel davranışçı terapinin elementlerini 
içermiş olup travmatik tecrübenin olumsuz etkilerini hafifletmeyi amaçlamaktadır. Müdahale, yüksek lisans seviyesindeki sosyal hizmet çalışanları tarafından aktarılmıştır.

Diğer iki çalışma da savaş ve çatışma sonrası hayatta kalan çocuklar için özel olarak geliştirilmiş bilişsel davranışçı grup bazlı, İyileşme Tekniklerinin Öğretilmesi [Teaching Recovery Techniques (TRT)] müdahalesini kullanmıştır. Öğrencileri semptomları hakkında eğiten ve uyum sağlamalarını kolaylaştırmak için başa çıkma stratejileri öğreten müdahale, iyileştirmekten ziyade gelecekte duyulacak ihtiyacı önlemeyi amaçlamaktadır (Smith ve ark., 2000). Barron ve arkadaşları (2013) programın beş haftalık Arapça tercümesini kullanırken, Ooi ve arkadaşlarının (2016) çalışmasında zaman kısıtlamaları sebebiyle seansların süreleri iki saatten bir saate ve müdahale 8 seanstan 5 seansa indirilmiştir. Jordans ve arkadaşları (2010) ise 5 hafta 15 seanslık sınıf bazlı müdahaleyi [Classroom-based Intervention (CBI)] kullanmıştır. Bu müdahale, bilişsel davranışsal, yaratıcı-dışavurumsal ve deneysel terapi kavramlarına dayanan eklektik bir modeldir.

\section{Stres Yaşayan Öğrenciler Arasında Dayanıklılığı Artırma Müdahalesi} (Enhancing Resiliency Among Students Experiencing Stress): Stres yaşayan öğrenciler arasında dayanıklılığı artırma müdahalesin kültüre uyarlanmış veya genişletilmiş versiyonları derlemeye dahil edilmiş üç çalışma tarafından kullanılmıştır. Stres yaşayan öğrenciler arasında dayanıklılığı artırma müdahalesi, 12 haftalık okul bazlı, öğretmenler tarafindan aktarılan; travmaya veya afete maruz kalmış ve tehdit altında hisseden çocuklar için kullanılan bir müdahale metodudur. Travmatik olayın direk olarak işlenmesinden kaçınılan müdahale, dayanıklılı̆̆ı artırmayı ve başa çıkma mekanizmalarını güçlendirmeyi amaçlamaktadır. Bunun için psikoeğitim materyalleri ve bilişsel davranışçı teknikleri kullanılır (Gelkopf ve Berger, 2009).

Gelkopf ve Berger (2009) tsunamiye maruz kalmış Sri Lankalı öğrenciler için bu müdahalenin kültüre uyarlanmış versiyonunu kullanmıştır. Çalışma başlamadan önce adaptasyon süreci, müdahaleyi küçük bir grup öğrenciye uygulayan Sri Lankalı ruh sağlığı uzmanları tarafından yürütülmüştür. Böylece hem kültüre hem de müdahaleye aşina olan ve öğrenciler tarafından da tanınan bir uygulayıcı grubu oluşturulmuştur.

Berger, Abu-Raiya ve Benatov (2016), Gazze savaşına maruz kalmış öğrenciler için programın genişletilmiş versiyonunu, toplum yanlısı yönelimleri geliştiren stres yaşayan öğrenciler arasında dayanıklılığı artırma müdahalesini [Enhancing resiliency among students experiencing stress-Pro-Social (ERASE-Stress-Pro-Social (ESPS))], kullanmıştır. Bu çalışma travma sonrası stresi azaltmanın yanında öğrencilerin azınlıklara karş1 önyargılı tutumlarını ve ayrımcı eğilimlerini de hafifletmeyi hedeflemektedir. $\mathrm{Bu}$ sebeple dört seans daha müdahaleye eklenmiş̧ir ve müdahale orijinal hali olan 12 seanstan 16 seansa çıkarılmıştır. 
Berger ve arkadaşları (2012) müdahaleyi şiddetli savaş kaynaklı travma yaşayan öğrenciler için genişleterek 16 seansa çıkarmıştır. Program, dînî uygulamalara ağırlık verilerek gerçekleştirimiştiri. Savaşın devam ettiği göz önüne alınarak, öz-olumlama, duygulanım düzenleme stratejileri, korkuyla baş etme ve sosyal beceriler konularının işlendiği dört seans daha müdahaleye dahil edilmiştir.

\section{Psikolojik Sağlamlığı İnşa Etme Müdahalesi [Building Resilience Intervention} (BRI)]: Psikolojik sağlamlığı inşa etme müdahalesi, kendileri için kullanmaları ve sınıfta kullanabilmeleri için öğretmenlere psikolojik sağlamlığı inşa eden araçları takdim eden bir eğitim programıdır. Müdahale birebir öğrenciler üzerinde kullanılmıyor olsa da temel hipotezi, öğretmenin artan psikolojik sağlamlığının öğrenciler üzerinde olumlu bir etkisi olacağı yönündedir (Baum ve ark., 2013). Baum ve arkadaşlarının (2013) çalışması, öğretmenlere 12 saatlik bir eğitim kursu sağlamış ve bu öğretmenlerin eğitim öncesi ve sonrası sınıflarını değerlendirerek bu müdahalenin etkisini incelemiştir.

\section{Ergenler İçin Travma ve Yas Birleşik Terapisi (TYBT) [Trauma and Grief Component Therapy for Adolescents (TGCT)] Sınıf Bazlı Müdahaleyle [Classroom-} Based Intervention (CBI)] Beraber: Layne ve arkadaşlarının (2008) çalışmasında müdahale için iki farklı terapi modelini birlikte kullanılmıştır. Bunlardan bir olan ergenler için travma ve yas birleşik terapisi (TYBT), travmaya maruz kalmış veya travmatik bir kayıp yaşamış, şiddetli endişe, işlevsel bozukluk ve gelişimsel bozukluklar yaşama riski taşıyan ergenler için geliştirilmiş 17 seans 4 modülden oluşan travma ve yas odaklı bir tedavi modelidir. Bu tedavi modeli endişeyi azaltmayı, olumlu uyum yeteneklerini geliştirmeyi ve sağlıklı gelişmeyi desteklemeyi; böylece ergenleri sorumlu vatandaşlar ve sağlıklı yetişkinler olmaya hazırlamayı amaçlamaktadır (Layne ve ark., 2008). TYBT dört modülünde psikoeğitim, travmayı işleme, yas odaklı müdahaleler ve gelişimsel ve geleceğe yönelik egzersizler kullanılmıştır. Araştırmaya katılan tüm öğrenciler aynı okullarda okuduğundan hem müdahale grubu hem de kontrol grubu, y1l boyunca devam eden okul bazlı müdahaleyi almıştır. Okul bazlı müdahale psikoeğitimden, gevşeme eğitiminden, baş etme becerilerinden, sosyal destek becerilerinden, duygu ve davranış düzenleme becerilerinden ve problem çözme becerilerinden oluşmaktadır. İki tedavi modeli de okul danışmanları tarafından savaşa maruz kalmış ergenlere uygulanmıştır.

\section{Karşılaştırıcılar}

Dahil edilen makaleler içinde en sık kullanılan karşılaştırıcı (ya da kontrol grubu) bekleme listesi olmuştur; dokuz çalışma bekleme listesi kullanmış ve kontrol gruplarının hiçbir müdahale almadığını rapor etmiştir (Barron ve ark., 2013; Baum ve ark., 2013; Berger ve ark., 2016, Berger ve ark, 2012; Gelkopf ve Berger, 2009; Jordans ve ark., 2010; Karam ve ark., 2008; Ooi ve ark., 2016; Tol ve ark., 2012). 
Görmez ve arkadaşları (2017) aynı grubu müdahale öncesi ve sonrası değerlendirip herhangi bir kontrol grubu kullanmamıştır. Layne ve arkadaşları (2008) müdahale grubu ve kontrol grubu aynı okulda olduğundan ve tüm okul yıl boyunca sinıf bazlı müdahaleyi aldığından, bir sınıf bazlı müdahaleyi kontrol grubu olarak kullanmıştır. Böylece, tedavi grubundaki ve kontrol grubundaki öğrencilerin hepsi bu okul bazlı müdahaleyi almıştır.

Salloum ve Overstreet'in (2008) çalışması tedavi grubuna uygulanan okul bazlı müdahaleyi kontrol grubuna bireysel tedavi şeklinde uygulamıştır.

\section{Çıktılar}

Travma Sonrası Stres Bozukluğu ( TSSB) Semptomları: Dahil edilen tüm çalışmalar travma sonrası stres bozukluğunu farklı ölçme araçları kullanarak ölçmüştür. $\mathrm{Bu}$ ölçme araçları arasında en çok kullanılanı beş çalışma tarafindan kullanılan Kaliforniya Üniversitesi TSSB Tepki İndeksi olmuştur. Kaliforniya Üniversitesi TSSB Tepki İndeksi, çocuklarda ve ergenlerde TSSB'yi ve travmatik stresi ölçen 17 maddelik bir kendi kendine rapor etme aracıdır (Pynoos, Rodriguez, Steinberg, Stuber ve Frederick, 1998). Katılımcılar, 5 puanlık likert ölçeğini kullanarak semptomları ne sıklıkta yaşadıklarını belirtmişlerdir; 0'dan (hiç yaşanmamış) 4'e (çok sık yaşanılan). $\mathrm{Bu}$ ölçüm arac1, iyi derecede geçerlilik (.70) ve iyi ila mükemmel test yeniden test güvenilirliğini göstermiştir (Chronbach alfa 0.90).

Layne ve arkadaşlarının (2008) randomize kontrollü çalışması travma ve yas odaklı grup tedavisi (TYBT) ile sınıf bazlı müdahalenin ve tek başına sınıf bazlı müdahalenin etkilerini karşılaştırmıştır. Tedavi öncesi ve tedavi sonrası değerlendirmeler ve 4 aylık takip analizleri yürütülmüştür. İki grup da ilk analizde TSSB'de anlamlı düşüşler göstermiştir $(\mathrm{p}<.001)$. Ancak, bu düşüşler tedavi grubunda (TYBT) yüksekken ( $\mathrm{d}=0.84)$, karşılaştırma grubunda orta büyüklükte olacak şekilde hesaplanmıştır $(\mathrm{d}=0.50)$. İki grup da takip analizlerinde TSSB'de anlamlı düşüşler göstermiştir ve bu düşüşler tedavi grubunda $(\mathrm{p}<001 \mathrm{~d}=1.74)$ karşılaştırma grubundan $(\mathrm{p}<.001 \mathrm{~d}=1.21)$ daha yüksek bulunmuştur.

Salloum ve Overstreet (2008) Kayıp ve Hayatta Kalma Ekibi okul bazlı müdahalesiyle bireysel okul bazlı müdahaleyi karşılaştırmıştır. Çalışma iki grupta da değişimlerin aynı olduğunu raporlamış ve sonuçlar bir arada verilmiştir. Kasırgaya maruz kalmış çocukların TSSB skorlarında anlamlı ve yüksek düşüşler hem ilk analizlerde ( $\mathrm{p}=.001$ $\mathrm{d}=1.16)$ hem de takip analizlerinde ( 3 hafta) $(\mathrm{p}=.001 \mathrm{~d}=1.82)$ gözlemlenmiştir.

Gelkopf ve Berger (2009) çalışmalarında, tsunamiye maruz kalmış çocuklar için uyguladıklarıstres yaşayan öğrenciler arasında dayanıklılığı artırma müdahalesinin TSSB 
semptomlarında anlamlı ve büyük düşüşlere sebep olduğunu raporlamıştır $(\mathrm{p}<0.001$ $\mathrm{d}=1.26$ ). Bu çalışmada kontrol grubundaki değişimler anlamlılık göstermemiştir.

Berger ve arkadaşlarının (2012) çalışması stres yaşayan öğrenciler arasında dayanıklılığı artırma müdahalesinin genişletilmiş formunun bekleme grubuyla karşılaştırıldığında TSSB'de büyük düşüşler sağladığını göstermiştir $(\mathrm{p}<.001 \mathrm{~d}=0.83)$.

Baum ve arkadaşları (2013) Psikolojik Sağlamlık Müdahalesindeki öğrencilerle bekleme listesindekileri karşılaştırmıştır. Değerlendirmeler tedavi grubunda bekleme listesiyle karşılaştıııldığında TSSB skorlarında orta düşüşler olduğunu göstermiştir $(\mathrm{p}=0.006 \mathrm{~d}=0.57)$.

İkinci en sık kullanılan TSSB ölçeği üç çalışma tarafindan kullanılan (Berger ve ark., 2016; Jordans ve ark., 2010; Tol ve ark., 2012) Çocuklar için TSSB Semptom Ölçeği [Child Post Traumatic Symptom Scale (CPTSS)] olmuştur. Çocuklar için TSSB Semptom Ölçeği, TSSB'yi semptomların yaşanma sıklığına göre değerlendiren 17 maddelik bir ölçüm aracıdır (Foa et al., 2001). Test tekrar test güvenirliği yüksektir (Spearmen-Brown katsayıs1 .85).

Jordans ve arkadaşları (2010) sınıf bazlı müdahalenin ve bekleme listesinin skorlarındaki değişimleri karşılaştırmak için bağımsız t testleri kullanmıştır. TSSB değişimleri tedavi grubunda zaman içinde anlamlı ve küçük düşüşler gösterse de (MönMson=2.45 p=.000 d=0.47) bu düşüş bekleme listesinde de neredeyse aynı seviyede hesaplanmıştır (Mön-Mson=2.39 p=.000 d=0.47).

Tol ve arkadaşları (2012) okul bazlı grup müdahalesindeki öğrencilerle bekleme listesindeki öğrencileri karşılaştırmış ve müdahale öncesinde, müdahaleden bir hafta sonra ve üç ay sonra değerlendirmeler yapmıştır. TSSB skorları yapılan analizlerde anlamlılık göstermemiştir. Ancak ileri analizler daha düşük seviyelerde savaş kaynaklı stres yaşayan çocukların TSSB'de daha iyi gelişim gösterdiğini ortaya koymuştur $(\mathrm{p}=0.024)$. Buna ek olarak çalışma, müdahalenin kız öğrenciler üzerinde kasitsız zararlı etkisi olduğunu bulmuştur. Bekleme listesindeki kız öğrenciler TSSB'de semptomlarında daha büyük düşüşler göstermişlerdir $(\mathrm{d}=.37)$.

Berger ve arkadaşları (2016) toplum yanlısı yönelimleri geliştiren stres yaşayan öğrenciler arasında dayanıklılığı artırma müdahalesi ile sosyal duygusal öğrenme programını [Social Skills (SS)] karşılaştırmak için kovaryans analizleri (ANCOVA) kullanmıştır. Değerlendirmeler müdahaleden bir hafta önce ve müdahaleden iki ay sonra olacak şekilde iki kere yapılmıştır. Sonuçlar TSSB'de anlamlı düşüşler olduğunu göstermiştir $(\mathrm{p}<.001)$.

Çalışmalardan ikisi Çocuklar için Revize Edilmiş Olayların Etkisi Ölçeğini [Children's Revised Impact of Event Scale (CRIES-13)] kullanmıştır (Barron ve ark., 2013; Ooi ve ark., 2016). Çocuklar için Revize Edilmiş Olayların Etkisi Ölçeği; yeniden 
yaşama, kaçınma ve aşırı uyarılma semptomlarını 4 puanlı ölçekte (hiç değil, nadiren, bazen, her zaman) ölçen 13 maddelik bir ölçüm aracıdır (Berger ve ark., 2016). Bu araç, iyi iç tutarlılık gösterir (Chronebach alpha .80) (Smith ve ark., 2003).

Barron ve arkadaşları (2013), randomize kontrollü çalışmalarında eşleştirilmiş t testleri ve kovaryans analizi kullanmıştır. Arapçaya çevrilmiş Çocuklar için Revize Edilmiş Olayların Etkisi Ölçeği müdahaleden bir ay önce ve üç hafta sonra uygulanmıştır. Çalışma sonucunda müdahale grubu TSSB'de anlamlı ve büyük düşüşler göstermiştir $(\mathrm{d}=0.76 \mathrm{p}<.005)$.

Ooi ve arkadaşları (2016) çalışmalarında müdahale grubundaki ve bekleme listesindeki katılımcıları müdahaleden 1 hafta önce ve müdahaleden hemen sonra değerlendirmiştir. Bekleme sürecinin ardından bekleme listesindeki katılımcılara da müdahale sağlandığından, 1 ay sonra yapılan takip değerlendirmeleri yalnızca müdahale grubu üzerinde yapılmıştır. Yapılan analizler sonucu müdahale grubundaki veya bekleme listesi grubundaki TSSB skorları anlamlılık göstermemiştir.

Karam ve arkadaşları (2008) TSSB değerlendirmesini Revize Edilmiş Çocuklar ve Ergenler İçin Teşhis Görüşme [Diagnostic Interview for Children and AdolescentsRevised (DICA-R)] ölçüm kriterlerine göre yapmıştır. Revize Edilmiş Çocuklar ve Ergenler İçin Teşhis Görüşme ölçüm aracı, majör depresif bozukluk, ayrılık anksiyete bozukluğu ve TSSB semptomlarını DSM-III-R kriterlerine göre değerlendiren bir tanı aracıdır (Karam ve ark., 2008). Bu çalışma sınıf bazlı psikososyal müdahaleyi alan grupla bekleme listesindeki grubu karşılaştırmış ve savaştan bir ay sonra, müdahaleden 3 hafta sonra ve müdahaleden bir yıl sonra değerlendirmeler yapmıştır. Çalışma sonucunda, müdahalenin TSSB semptomları üzerinde anlamlı bir etkisi olduğu gözlenmemiştir.

Görmez ve arkadaşları (2017) çalışmalarında Çocuk Travma Sonrası Stres-Reaksiyon İndeksini [Child Post-traumatic stress-reaction Index (CPTS-RI)] kullanmıştır. Çocuk Travma Sonrası Stres-Reaksiyon İndeksi, üç kategoride çocukların travma sonrası stres reaksiyonlarını ölçen, 20 maddelik bir ölçüm aracıdır (Pynoos ve ark, 1987). Bu üç kategori ise yeniden yaşama, kaçınma ve aşırı uyarılma kategorileridir. Katılımcılar kendi semptomlarını son aydaki yaşanma sıklıklarına göre 0 (hiç)'dan 4 (çoğu zaman)'e kadar puanlamaktadır. Görmez ve arkadaşları (2017) aynı öğrenci grubunu grup bilişsel davranış̧̧ı müdahalesinden öne ve sonra değerlendirmiş ve herhangi bir kontrol grubu kullanılmamıştır. Belirti kümeleri eşleştirilmiş t-testleri ile incelenmiş ve Pearson korelasyonları ile değişkenler arasındaki ilişki incelenmiştir. Toplam TSSB skorlarında anlamlı ve küçük düşüşler gözlenmiştir $(\mathrm{p}=0.011 \mathrm{~d}=0.47)$. TSSB alt kategorileri analiz edildiğinde ise yeniden yaşama kategorisinde anlamlı ve orta düşüşler $(\mathrm{p}=0.001$ $\mathrm{d}=0.68$ ), aşırı uyarılma kategorisinde ise anlamlı ve küçük düşüşler ( $\mathrm{p}=0.015 \mathrm{~d}=0.44$ ) görülmüştür. TSSB kaçınma alt kategorisi ise anlamlılık göstermemiştir ( $\mathrm{p}=0.280)$. 
Depresyon. İncelenen makalelerin çoğu, depresyonu incelemek için ayrı ölçüm araçlarını kullanmıştır. Depresyon Öz Değerlendirme Ölçeği [Depression Self-rating Scale (DSRS)] değerlendirilen beş çalışma tarafindan kullanılan bir ölçek olmuştur (Barron ve ark., 2013; Jordans ve ark., 2010; Layne ve ark., 2008; Ooi ve ark., 2016; Tol ve ark., 2012). Depresyon Öz Değerlendirme Ölçeği, depresif bozukluğu, çocukların ve ergenlerin günlük yaşamdaki işleyişlerine olan etkileri bakımından ölçen 18 maddelik bir ölçüm aracıdır (Birleson, 1981). Bu ölçekte katılımcılar sorulara şu üç seçeneğe göre puan vermiştir; çoğu zaman, bazen ve asla. Depresyon Öz Değerlendirme Ölçeği yüksek test tekrar test güvenilirliği $(\alpha=.80)$ iyi iç tutarlılık $(\alpha=.86)$ göstermektedir (Birleson, 1981). Depresif ve depresif olmayan maddeler mevcuttur ve ölçek buna göre puanlanmıştır. Elde edilebilecek en yüksek puan 36'dır ve yüksek puanlar yüksek depresif eğilimlere işaret etmektedir (Denda, Kako, Kitagaea ve Koyama, 2006).

Layne ve arkadaşları (2008) yapılan ilk analizlerde depresyonda yalnızca müdahale grubunda anlamlı ve küçük düşüşler gözlendiğini rapor etmiştir $(\mathrm{p}<.05 \mathrm{~d}=0.28)$. Takip analizlerinde ise müdahale grubunda anlamlı ve büyük düşüşler $(\mathrm{p}<.001 \mathrm{~d}=1.39)$, kontrol grubunda ise orta düşüşler $(\mathrm{p}<.01 \mathrm{~d}=0.70)$ gözlenmiştir.

Jordans ve arkadaşları (2010), tedavi grubunun depresyon seviyelerinde anlamlı ve orta düşüşlerin olduğu $(\mathrm{p}=.000 \mathrm{~d}=.46)$ sonucuna varmıştır. Tol ve arkadaşları (2012) ise müdahalenin herhangi bir anlamlı sonuca ulaşmadığını rapor etmiş̧ir. Barron ve arkadaşlarının (2013) çalışması, İyileşme Tekniklerinin Öğretilmesi müdahale grubunda bekleme listesiyle kıyaslandığında depresyonda anlamlı ve büyük azalmaların olduğu sonucuna varmıştır $(\mathrm{p}<.005 \mathrm{~d}=1.24)$. Ooi ve arkadaşlarının (2016) çalışması yalnızca depresyon semptomlarında anlamlılık göstermiştir. İyileşme Tekniklerinin Öğretilmesi müdahalesinden hemen sonra anlamlı ve küçük düşüşler $(\mathrm{p}<0.001 \mathrm{~d}=0.42)$ gözlenmiştir ve bu düşüşlerin 3 ay sonra yapılan takip analizlerinde orta büyüklükte sürdüğü $(\mathrm{p}<0.01$ $\mathrm{d}=0.54$ ) raporlanmıştır.

Karam ve arkadaşları (2008) majör depresif bozukluğu ölçmek için Revize Edilmiş̧ Çocuklar ve Ergenler İçin Teşhis Görüşme ölçeğini kullanmış ve sınıf bazlı müdahaleyi alan öğrencilerle bekleme listesindeki öğrencileri karşılaştırmıştır. Çalışmanın sonuçları majör depresif bozuklukta bir anlamlılı̆ga ulaşmamıştır. Salloum ve Overstreet (2008), ve katılımcıların nasıl hissettiklerini ve son iki haftada nasıl davrandıklarını değerlendiren 33 maddeden oluşan Ruh Hali ve Duygular Anketi-Çocuk Versiyonu [The Mood and Feelings Questionnaire-Child Version (MFQ-C)] depresyon ölçeğini kullanmıştır. Bu anket iyi bir kriter geçerliliği ve güvenilirliği göstermiştir $(\alpha=, 95)$ (Daviss ve ark, 2006) ve iç tutarlılık bu çalışmanın örneklemi için iyi seviyededir ( $\alpha$ $=.87$ ). Bu çalışma, okul temelli Kayıp ve Hayatta Kalma Ekibi grup müdahalesini ve okul temelli bireysel tedaviyi karşılaştırmış ve gruplar arasında depresyon sonuçlarında anlamlı bir fark bulamamıştır. Bu nedenle, iki grubun sonuçları birlikte rapor edilmiştir. Depresyonda, yapılan ilk analizlerde orta bir düşüş $(\mathrm{p}=.001 \mathrm{~d}=.53)$ ve takip analizlerinde 
büyük düşüşler ( $\mathrm{p}=.001 \mathrm{~d}=1.11$ ) gözlemlenmiş; dolayısıyla bu düşüşlerin zaman içinde arttı̆̆ ortaya koyulmuştur.

Berger ve arkadaşları (2009) depresyonu 7 maddelik kısa Beck Depresyon Envanteri (BDE) [Beck Depression Inventory (BDI)] ile ölçmüştür. Tsunamiye maruz kalmış çocuklarla yapılan bu çalışmanın sonuçlarına göre; Stres yaşayan öğrenciler arasında dayanıklılığı artırma müdahale grubu, kontrol grubuna kıyasla depresyon skorlarında anlamlı ve büyük düşüşler göstermiş̧ir ( $\mathrm{p}<0.001 \mathrm{~d}=1.19)$.

Anksiyete. Anksiyeteyi ölçen çalışmaların beşi Çocuklarda Anksiyete Tarama Ölçeğini kullanmıştır (Baum ve ark., 2013; Berger ve ark., 2016, Berger ve ark.,2012; Jordans ve ark., 2010; Tol ve ark., 2012). Çocuklarda Anksiyete Tarama Ölçeği, panik / somatik, ayrılık anksiyetesi, yaygın kaygı ve okul fobisi alanlarını kullanarak 0 puandan 4'e (çok fazla) 4 puanlık bir ölçekte anksiyeteyi ölçen 41 maddelik bir kendini değerlendirme envanteridir (Birmaher ve ark., 1997). Bu ölçek onaylanmış bir ölçektir (dahili güvenilirlik $\alpha=.35$, test-tekrar test güvenilirliği $\alpha=.84$ ) (Birmaher ve ark, 1997).

Jordans ve arkadaşları (2010) Çocuklarda Anksiyete Tarama Ölçeğinin beş maddelik versiyonunu kullanmıştır. $\mathrm{Bu}$ çalışmanın sonuçlarına göre sınıf bazlı müdahale grubundaki katılımcılar anksiyete seviyelerinde anlamlı ve küçük düşüşler göstermiştir $(\mathrm{p}=.017 \mathrm{~d}=.27)$. Envanterin yalnızca genel anskiyete ve ayrılık anksiyetesi bölümlerini kullanan Berger ve arkadaşları (2012), genel anksiyetede $(\mathrm{p}<.001 \mathrm{~d}=0.50)$ ve ayrılık anksiyetesinde $(\mathrm{p}<.001 \mathrm{~d}=0.50)$ anlamlı ve orta düşüşler gözlemlemiştir. Tol ve arkadaşları (2012) da Çocuklarda Anksiyete Tarama Ölçeğinin beş maddelik versiyonunu kullanmıştır. $\mathrm{Bu}$ çalışma müdahalenin anksiyete semptomları üzerinde istatistiksel olarak anlamlı bir etkisi olmadığı sonucuna varmıştır. Baum ve arkadaşları (2013), aynı ölçeğin ayrılık anksiyetesi alt ölçeğini kullanmıştır ve sonuçlar müdahale grubunda orta düşüşlerin olduğunu göstermiştir $(\mathrm{p}<0.001 \mathrm{~d}=0.51$ ). Berger ve arkadaşları (2016) envanterin yalnızca genel anksiyete alt ölçeğini kullanmış ve anksiyete semptomlarında herhangi bir anlamlı düşüş raporlamamıştır.

Karam ve arkadaşları (2008) savaşa maruz kalmış çocuk ve ergenlerin ayrılık anksiyetelerini ölçmek için Çocuklar ve Ergenler İçin Teşhis Görüşme envanterini kullanmıştır. Bu çalışma sınıf bazlı müdahaleden sonra ayrılık anksiyetesi sonuçlarında istatistiksel olarak anlamlı herhangi bir değişim olduğu sonucuna ulaşmamıştır.

Görmez ve arkadaşları (2017), savaşa maruz kalmış çocuklarda anksiyete semptomlarını ölçümlemek için; 38 kendi kendine puanlama maddesi içeren, anksiyete ile ilgili bozukluklar ve obsesif kompulsif bozukluk alt ölçeklerinden oluşan Spence Çocuk Anksiyete Ölçeğini [Spence Children's Anxiety Scale (SCAS)] kullanmıştır. $\mathrm{Bu}$ çalışmanın sonuçlarına göre, müdahale sonrası değerlendirmeler, toplam anksiyete puanlarında ortalama bir düşüş göstermiştir $(p=0.001 \mathrm{~d}=0.73)$. 


\section{Tartışma}

Bu araştırma, farklı türlerde okul bazlı müdahalelerin savaş veya doğal afet travmasına maruz kalan çocuk veya ergenlerde TSSB, depresyon ve anksiyete belirtileri üzerindeki etkilerinin sistematik bir derlemesini gerçekleştirmiştir. Dahil edilen çalışmalara genel olarak bakıldığında, birkaç çalışma dışında, okul bazlı müdahaleler, katılımcıların TSSB semptomlarında önemli düşüşlere neden olmaktadır. Bekleme listesini okul temelli bir müdahale ile karşılaştıran sekiz çalışmadan beşi, müdahale grubunun TSSB puanlarında önemli bir azalma olduğunu bildirmiştir (bakınız Tablo 2). Diğer üç çalışma, bekleme listesi ile yapılan müdahaleleri karşılaştırmış ve TSSB'de istatistiksel olarak hiçbir anlamlılık bulamamıştır. Bu çalışmalardaki müdahaleler, öğretmenler veya okul danışmanları tarafından aktarılan diğer müdahalelerin aksine paraprofesyoneller (Tol ve ark., 2012), yardımcı kolaylaştırıcılar (Ooi ve ark., 2016) ve araştırma görevlileri tarafından (Jordans ve ark., 2010) uygulanmıştır.

Araştırmaya dahil edilen çalışmalardan biri diğerlerinden farklı olarak öğrencilere değil öğretmenlere uygulanan bir müdahale modeli olmuştur (Baum ve ark., 2013). $\mathrm{Bu}$ çalışma, direk olarak öğrenciler için sistematik bir müdahale uygulamamış olsa da öğretmenlere savaş kaynaklı travma ile başa çıkma becerilerinin ve psikolojik sağlamlığı inşa etmek için kullanabilecek materyallerin öğretilmesinin öğrencilerin TSSB semptomlarında orta derecede düşüşler olmasını sağlayabileceğini göstermiştir. Bu durum, yakın zamanda yapılan sistematik derlemelerdeki okul temelli müdahalelerin başarısının bir nedenin de öğrenciler tarafından yakından tanınan ve güvenilen okul personeli tarafından verilmeleri olduğu savını (Sullivan ve Simonson, 2016) desteklemektedir. Sullivan ve Simonson'un (2016) sistematik derlemesi, öğretmenlerin okul bazlı müdahaleleri uygulamada en az klinisyenler kadar başarılı olduğunu bulmuştur. Araştırmada yer alan ve müdahalenin öğretmenler tarafından uygulanmış olduğu Karam ve arkadaşlarının.(2008) çalışması, hiçbir semptom grubunda anlamlılık göstermemiştir. Bu durum, müdahaleyi veren öğretmenlerin yalnızca bir gün eğitim almış olması ve müdahalenin 12 gün artarda uygulanmış olmasından kaynaklanabilir. Ayrıca bu çalışmada öğretmenlere süpervizyon da sağlanamamıştır.

Araştırmada okul bazlı müdahalelerle diğer okul bazlı müdahaleleri karşılaştıran ve TSSB semptomlarını ölçen iki çalışma bulunmaktadır (Layne ve ark., 2008; Salloum ve Overstreet, 2008). Bu çalışmalardan biri okul temelli bireysel müdahaleyi ve grup müdahalesini karşılaştırmış ve bu iki müdahalenin de TSSB'de büyük semptom düşüşlerine yol açtığını bulmuştur (Salloum ve Overstreet, 2008). Diğer çalışmada ise, iki okul temelli grup terapisi alan bir grup ile sadece bir grup terapisi alan bir grup 
karşılaştırılmıştır (Layne ve ark., 2008). Bu çalışmanın sonuçlarına göre, iki tedaviyi birden alan grup TSSB'de daha fazla azalma göstermiştir.

Dahil edilen çalışmalar arasında, savaş travması geçiren öğrenciler için TSSB'de en fazla düşüşü gösteren çalışmalar, en uzun müdahale programlarına sahip olanlar olmuştur (sırasıyla Berger ve ark., 2012; Layne ve ark., 2008). Bu bakımdan, müdahalenin uzunluğunun TSSB semptom düşüşlerini etkileyen faktörlerden biri olduğu söylenebilir.

Doğal afet ve savaş travmasına uygulanan müdahalelerin TSSB açısından karşılaştırılması, doğal afetlere yönelik okul bazlı müdahalelerin daha büyük semptom iyileşmelerine sebep olduğunu göstermektedir. Tsunamiye maruz kalmış öğrenciler üzerinde, bekleme listesiyle Stres yaşayan öğrenciler arasında dayanıklılığı artırma müdahalesini karşılaştıran çalışma, müdahale grubunda TSSB'de büyük semptom düşüşleri kaydetmiştir (Gelkopf ve Berger, 2009). Kasırgaya maruz kalmış öğrencilerle yürütülen ve okul bazlı grup müdahalesiyle okul bazlı bireysel müdahalenin karşılaştırıldığı çalışma ise TSSB'de en büyük düşüşlerin görüldüğü çalışmalardan biri olmuştur (Salloum ve Overstreet, 2008). Bu, doğal afet ve savaş travmasının farklılaşmasından kaynaklanıyor olabilir. Dünya Sağlık Örgütü’ne (Girolamo ve Orley, 1992) göre yıkımın insan yapımı olduğunu bilmek, durumla başa çıkmayı zorlaştırmaktadır. Bu nedenle, doğal afetlere maruz kalan çocuklar ve gençler, okul bazlı müdahalelerden savaş travmalarına maruz kalanlara kıyasla daha çok faydalanmış olabilirler.

Araştırmaya dahil edilen makalelerin çoğu, depresyon ve anksiyete belirtilerinde düşüş desenleri göstermiştir. Bu etki büyüklüğü desenleri de öğretmenlerin müdahalelerde uygulayıcı olmasının semptom azaltmada önemli bir faktör olabileceğini göstermiştir. Barron ve arkadaşlarının (2013) yaptığı çalışmada, öğretmenlerin savaşa maruz kalan çocuklara verdiği İyileşme Tekniklerinin Öğretilmesi müdahalesi, depresyon belirtilerinde en yüksek düşüşlere ulaşmıştır $(\mathrm{d}=1.24)$. Öğretmenler tarafından doğal afetlere maruz kalan çocuklara verilen stres yaşayan öğrenciler arasında dayanıklılığ artırma müdahalesi (Gelkopf ve Berger, 2009), depresyon için ikinci en büyük etki büyüklüğ̈ne sahip olan çalışma olmuştur $(\mathrm{d}=1.19)$. Müdahalenin öğretmenler tarafından verildiği bir başka çalışma ise, merak uyandırıcı sonuçlara ulaşmıştır (Layne ve ark., 2008). Bu çalışmanın sonuçlarına göre, öğrenciler müdahaleden hemen sonra depresyon seviyelerinde küçük düşüşler göstermiş olsa $\mathrm{da}(\mathrm{d}=0.28), 4$ ay sonra yapılan takip analizlerinde düşüşler yüksek bulunmuştur $(\mathrm{d}=1.39)$.

Müdahalenin öğretmenler tarafından verilmediği diğer çalışmalar, depresyon belirtilerinde küçük ve orta dereceli düşüşler kaydetmiştir (Jordans ve ark., 2010 
$\mathrm{d}=0.46$; Ooi ve ark., $2016 \mathrm{~d}=0.42$; Salloum ve Overstreet, $2008 \mathrm{~d}=0.53$ ). Depresyon ölçümü yapılan diğer iki çalışma ise anlamlı sonuçlar vermemiştir (Karam ve ark., 2008; Tol ve ark., 2012). TSSB ve anksiyete puanlarında da anlamlı bulunmayan Karam ve arkadaşlarının (2008) çalışması, müdahalenin ve öğretmen eğitimlerinin kısa süresi ve öğretmenlerin süpervizyon alamaması gibi nedenlerle başarısız olmuş olabilir. $\mathrm{Bu}$ çalışma diğer çalışmaların aksine DSM-III kriterlerine göre semptom ölçümleri gerçekleştirmiştir. Bu da sonuçları etkileyen önemli nedenlerden biri olarak görülebilir.

Tolve arkadaşlarının çalışması (2012), herüç semptomda da başarısızsonuçlargösteren makalelerden biri olmuştur. Bu çalışma ciddi metodolojik problemler göstermemiş olsa da müdahale öğretmenler tarafından aktarılmamış ve diğer müdahalelere kıyasla kısa sürmüştür. $\mathrm{Bu}, \mathrm{bu}$ araştırmanın, uzun süreli ve öğretmenler tarafından verilen okul temelli müdahalelerin daha başarılı olduğu argümanını desteklemektedir.

Anksiyete belirtilerinde, öğretmenlerin aktardığı müdahaleler, semptom düzeylerinde orta düşüşler sağlamıştır (Baum ve ark., $2013 \mathrm{~d}=0.50$; Berger ve ark., $2012 \mathrm{~d}=0.51$ ). Müdahalenin öğrencilere paraprofesyoneller tarafından ulaştırıldığı çalışma (Jordans ve ark., 2010), anksiyete düzeylerinde küçük azalmalar olduğunu bildirmiştir $(\mathrm{d}=0.27)$. Doğal afetlere maruz kalan çocuklarla çalışan her iki çalışmada da anksiyete belirtisi ölçümleri yapılmamıştır (Gelkopf ve Berger, 2009; Salloum ve Overstreet, 2008).

Hangi müdahalenin daha etkili olduğu konusunda net bir desen bulunamamakla birlikte, stres yaşayan öğrenciler arasında dayanıklılığı artırma müdahalesinin TSSB, depresyon ve anksiyete semptomlarını azaltmada en başarılı müdahale olduğu savunulabilir. Bunun nedeni, TSSB (Gelkopf ve Berger, 2009), depresyon (Gelkopf ve Berger, 2009) ve anksiyete (Berger ve ark. 2012) semptomlarının düşüşünde en yüksek etki büyüklüğüne sahip çalışmalarda stres yaşayan öğrenciler arasında dayanıklılığı artırma müdahalesinin kullanılmış olmasıdır.

Tüm makaleler kalite değerlendirme araçları ile belli kriterlere göre incelenmiş ve hepsi kabul edilebilir kalitede bulunmuş olsa da dahil edilen çalışmaların bazılarında bulguları etkileyebilecek metodolojik problemler de bulunmaktadır. Örneğin, küçük bir örneklem kullanmak, Görmez ve arkadaşlarının (2017) çalışmasının sonuçlarını etkilemiş olabilir. Bazı çalışmalar da katılımcıların özelliklerinde farklılıklar olduğunu rapor etmiştir (Baum ve ark., 2013; Ooi ve ark., 2016). Travmaya maruz kalma ve semptom şiddetindeki farklılıklar bulguların genellenebilirliğini tehlikeye atmış olabilir. Bir diğer önemli husus ise bazı çalışmaların katılımcıların ve değerlendiricilerin üzerinde körleme yapılıp yapılmadığını bildirmemesidir (Barron ve ark., 2013; Baum ve ark., 2013; Gelkopf ve Berger, 2009; Karam ve ark., 2008; Ooi ve ark., 2016). Bu, potansiyel yanlllık problemlerine yol açabilecek bir eksikliktir. 


\section{Sinırlamalar ve Uygulamalar}

Bu çalışmanın bir kısıtlılığı, doğal afet kaynaklı travma konusunda savaş kaynaklı travmadan daha az çalışma içermesidir. Makalelerin kalite değerlendirmesi sonrasında düşük kalitede bulunan çalışmaların çıkarılmasından sonra doğal afet travması içeren makalelerin sayısında bir düşüş yaşanmıştır.

Ayrıca, çalışmada çocuk ve ergenlerin birlikte ele alınmasına rağmen bu ikisi arasında net bir ayrım yapılamaması bu çalışmanın sınırlamalarından biri olarak görülebilir. Bu durum bazı çalışmaların geniş bir yaş aralığını ele almasından (Görmez ve ark., 2017; Karam ve ark., 2008; Ooi ve ark., 2016) ve semptom değişikliklerinin yaşa özel olarak raporlanmamasından kaynaklanmaktadır.

$\mathrm{Bu}$ çalışma, okul temelli müdahalelerin, doğal afetlere maruz kalan çocuk ve ergenlerde TSSB semptom seviyelerinin azaltılmasında büyük bir etkiye sahip olduğuna, savaşa maruz kalanlar üzerinde ise orta ve büyük bir etkiye sahip olduğuna dair kanıtlar bulmuştur. Bu bulgu, Rolfsnes ve Idsoe'nin (2011) travmatize olmuş çocuk ve ergenler için okul bazlı müdahaleler üzerine yaptığı sistematik derleme ve meta analizle desteklenmektedir. $\mathrm{Bu}$ derleme, 19 okul bazlı müdahalenin TSSB semptom düşüşleri üzerinde orta-büyük etkiye sahip olduğu sonucuna varmıştır (toplam etki büyüklüğ̈̈=0,68 olarak bulunmuştur).

Öğretmenler tarafindan verilen müdahaleler depresyonda büyük değişikliklere anksiyetede ise orta düşüşlere sebep olurken, diğer müdahaleler orta ve küçük seviyelerde gelişmelere yol açmıştır. Anksiyete semptomları doğal afet travması konusundaki çalışmalarda ölçülmediğinden yalnızca savaş sonrası yapılan çalışmalardaki anksiyete semptomları yorumlanabilmiştir.

Doğal afet veya savaş kaynaklı travma yaşayan çocukların TSSB, depresyon ve anksiyete semptomları üzerinde öğretmenler tarafindan aktarılan ve uzun süren müdahalelerin kanıtlanan başarısı göz önüne alındığında, gelecek çalışmalar müdahaleyi uygulayanlar olarak öğretmenlere ve müdahalenin süresi olarak daha uzun süren müdahalelere öncelik verebilir. Bu Fu ve Underwood'un (2015) TSSB semptomları üzerine yaptığı meta analizle de desteklenmektedir, bu meta analiz öğretmenlerin müdahale uygulayıcı olduğu durumlarda okul bazlı müdahalelerin daha etkili olduğunu göstermiştir.

Anksiyete ve depresyonda etkili olduğuna dair kanıtlar olmasına rağmen, okul temelli müdahaleler daha çok TSSB semptomlarına odaklanmış görünmektedir. $\mathrm{Bu}$ nedenle, okul bazlı müdahaleler uygulandığında katılımcıların semptomlarında daha başarılı sonuçlar elde edebilmek için gelecekteki çalışmaların anksiyete ve depresyona TSSB kadar yer vermesi ve bunların tedavisi için ek unsurlar içermeleri önerilebilir. 


\section{Kaynakça}

American Academy of Pediatrics. (2004). School-based Mental Health Services. Pediatrics, 113(6).

American Psychiatric Association \& American Psychiatric Association. Task Force on DSM-IV (2000), Diagnostic and statistical manual of mental disorders: DSM-IV-TR, 4th, text revision. edn, American Psychiatric Association, Washington, DC.

Attanayake, V., McKay, R., Joffres, M., Singh, S., Burkle, F., \& Mills, E. (2009). Prevalence of mental disorders among children exposed to war: a systematic review of 7,920 children. Medicine, Conflict, and Survival, 25(1), 4-19. https://doi.org/10.1080/13623690802568913.

Barron, I. G., Abdallah, G., \& Smith, P. (2013). Randomized Control Trial of a CBT Trauma Recovery Program in Palestinian Schools. Journal of Loss and Trauma, 18(4), 306-321. https:// doi.org/10.1080/15325024.2012.688712.

Baum, N. L., Cardozo, B. L., Pat-Horenczyk, R., Ziv, Y., Blanton, C., Reza, A., ... Brom, D. (2013). Training Teachers to Build Resilience in Children in the Aftermath of War: A Cluster Randomized Trial. Child and Youth Care Forum, 42(4), 339-350. https://doi.org/10.1007/ s10566-013-9202-5.

Berger, R., Abu-Raiya, H., \& Benatov, J. (2016). Reducing primary and secondary traumatic stress symptoms among Educators by Training Them to Deliver a Resiliency Program (ERASE-Stress) following the christchurch earthquake in New Zealand. American Journal of Orthopsychiatry, 86(2), 236-251. https://doi.org/10.1037/ort0000153.

Berger, R., Gelkopf, M., \& Heineberg, Y. (2012). A teacher-delivered intervention for adolescents exposed to ongoing and intense traumatic war-related stress: A quasi-randomized controlled study. Journal of Adolescent Health, 51(5), 453-461. https://doi.org/10.1016/j.jadohealth.2012.02.011.

Birleson P. (1981) The validity of depressive disorder in childhood and the development of a selfrating scale: a research report, J. Child Psychol. Psychiat., 22, 73-88.

Birmaher, B., Khetarpal, S., Brent, D., Cully, M., Balach, L., Kaufman, J., \& Neer, S. M. (1997) The Screen for Child Anxiety Related Emotional Disorders (SCARED): Scale construction and psychometric characteristics, Journal of the American Academy of Child \& Adolescent Psychiatry, 36, 545-553. http://dx.doi.org/10.1097/00004583-199704000-00018.

Bonanno, G. A., \& Mancini, A. D. (2008). The Human Capacity to Thrive in the Face of Potential Trauma. Pediatrics, 121(2), 369-375. https://doi.org/10.1542/peds.2007-1648.

Centre for Reviews \& Dissemination, C. (2009). Systematic Reviews: CRD's guidance for Undertaking Reviews in Health Care: Centre for Reviews and Dissemination.

Colman, A. M. (2015). A Dictionary of Psychology (4 ed.). Oxford University Press.

Daviss, W. B., Birmaher, B., Melhem, N. A., Axelson, D. A.,Michaels, S. M., \& Brent, D. A. (2006). Criterion validity of the mood and feelings questionnaire for depressive episodes in clinic and non-clinic subjects, Journal of Child Psychology and Psychiatry, 47, 927-934.

Denda, K., Kako, Y., Kitagawa, N., \& Koyama, T. (2006) Assessment of depressive symptoms in japanese school children and adolescents using the birleson depression self-rating scale, Journal of Psychiatry in Medicine, 36 (2), 231-24. doi: 10.2190/3YCX-H0MT-49DK-C61Q. 
Dimitry, L. (2012). A systematic review on the mental health of children and adolescents in areas of armed conflict in the Middle East. Child: Care, Health and Development, 38(2), 153-161. https://doi.org/10.1111/j.1365-2214.2011.01246.x.

Dyregrov, A., Gupta, L., Gjestad, R., \& Mukanoheli, E. (2000). Trauma Exposure and Psychological Reactions to Genocide Among Rwandan Children, 13(1), 3-21.

Effective Public Health Practice. (2015). Dictionary for the Effective Public Health Practice Project Quality Assessment Tool For Quantitative Studies, 4. http://www.ephpp.ca/index.html adresinden edinilmiştir.

Elbedour, S., Onwuegbuzie, A. J., Ghannam, J., Whitcome, J. A., \& Hein, F. A. (2007). Posttraumatic stress disorder, depression, and anxiety among Gaza Strip adolescents in the wake of the second Uprising (Intifada). Child Abuse and Neglect, 31(7), 719-729. https://doi. org/10.1016/j.chiabu.2005.09.006.

Foa, E.B., Treadwell, K., Johnson, K., \& Feeny, N. (2001) Child PTSD symptom scale (CPSS): Validation of a measure for children with PTSD, Journal of Clinical Child Psychology, 30, 376-384.

Fu, C., \& Underwood, C. (2015). A meta-review of school-based disaster interventions for child and adolescent survivors. Journal of Child and Adolescent Mental Health, 27(3), 161-171. https://doi.org/10.2989/17280583.2015.1117978.

G. de Girolamo, \& Orley, J. (1992). Psychosocial consequences of Disasters. Prevention and Management WHO_MNH_PSF_91.3_REV.1.pdf.http://apps.who.int/iris/ bitstream/10665/58986/1/WHO_MNH_PSF_91.3_REV.1.pdf adresinden edinilmiştir.

Garfin, D. R., Silver, R. C., Gil-Rivas, V., Guzmán, J., Murphy, J. M., Cova, F., ... Guzmán, M. P. (2014). Children's reactions to the 2010 Chilean earthquake: The role of trauma exposure, family context, and school-based mental health programming. Psychological Trauma: Theory, Research, Practice, and Policy, 6(5), 563-573. https://doi.org/10.1037/a0036584.

Gelkopf, M., \& Berger, R. (2009). A school-based, teacher-mediated prevention program (ERASEStress) for reducing terror-related traumatic reactions in Israeli youth: a quasi-randomized controlled trial. Journal of Child Psychology and Psychiatry, and Allied Disciplines, 50(8), 962-971. https://doi.org/10.1111/j.1469-7610.2008.02021.x.

Goenjian, A. K., Molina, L., Steinberg, A. M., Fairbanks, L. A., Alvarez, M. L., Goenjian, H. A., \& Pynoos, R. S. (2001). Among Nicaraguan Adolescents After Hurricane Mitch. American Journal of Psychiatry, 158(May), 788-794.

Gormez, V., Kılı̨̧, H. N., Orengul, A. C., Demir, M. N., Mert, E. B., Makhlouta, B., ... Semerci, B. (2017). Evaluation of a school-based, teacher-delivered psychological intervention group program for trauma-affected Syrian refugee children in Istanbul, Turkey. Psychiatry and Clinical Psychopharmacology, 27(2), 125-131. https://doi.org/10.1080/24750573.2017.1304748.

Guterman, N. B., Hahm, H. C., \& Cameron, M. (2002). Adolescent victimization and subsequent use of mental health counseling services. Journal of Adolescent Health, 30(5), 336-345. https:// doi.org/10.1016/S1054-139X(01)00406-2.

Hanson, R. F., \& Jobe-shields, L. (2017). Trauma-Focused Cognitive - Behavioral Therapy for Children and Adolescents, 2. 
Jaycox, Lisa H. Morse, Lindsey K. Tanielian, Terri. Stein, B. D. (2006). How Schools Can Help Students Recover from Traumatic Experiences: A Tool Kit for Supporting Long-Term Recovery. https://doi.org/10.1016/j.evopsy.2014.10.003.

Jaycox, L. H., Cohen, J. A., Mannarino, A. P., Walker, D. W., Langley, A. K., Gegenheimer, K. L., ... Schonlau, M. (2010). Children's Mental Health Care Following Hurricane Katrina: A field Trial of Trauma Focused Psychotherapies. Journal of Traumatic Stress, 23(2), 223-231.

Jordans, M. J. D., Komproe, I. H., Tol, W. A., Kohrt, B. A., Luitel, N. P., MacY, R. D., \& De Jong, J. T. V. M. (2010). Evaluation of a classroom-based psychosocial intervention in conflict-affected Nepal: A cluster randomized controlled trial. Journal of Child Psychology and Psychiatry and Allied Disciplines, 51(7), 818-826. https://doi.org/10.1111/j.1469-7610.2010.02209.x.

Kar, N. (2009). Psychological impact of disasters on children: review of assessment and interventions, 5(1), 5-11. https://doi.org/10.1007/s12519-009-0001-x.

Karam,E.G.,J.,F.,A.N.,K., C.C., T., N., M.,Z.,M., ,. Dimassi,H.(2008). Effectiveness and specificity of a classroom-based group intervention in children and adolescents exposed to war in Lebanon. World Psychiatry,7(2),103109.http://www.ncbi.nlm.nih.gov/pubmed/18560511\%0Ahttp:// www.pubmedcentral.nih.gov/articlerender.fcgi?artid=PMC2430518\%0Ahttp://ovidsp. ovid.com/ovidweb.cgi?T $=$ JS\&PAGE $=$ reference $\& D=$ emed $11 \& N E W S=N \& A N=352760044$ adresinden edinilmiştir.

Kilmer, R. P., Gil-Rivas, V., \& MacDonald, J. (2010). Implications of major disaster for educators, administrators, and school-based mental health professionals: Needs, actions, and the example of Mayfair Elementary. In R. P. Kilmer, V. Gil-Rivas, R. G. Tedeschi, \& L. G. Calhoun (Eds.), Helping families and communities recover from disaster: Lessons learned from hurricane Katrina and its aftermath (pp. 167-191). Washington, DC, US: American Psychological Association.

Laor, N., Wolmer, L, Spirman S. \& Wiener Z. (2003) Facing war, terrorism, and disaster: toward a child-oriented comprehensive emergency care system, Child and Adolescent Psychiatric Clinics of North America, 12(2), pp 343-361.

Layne, C. M., Saltzman, W. R., Poppleton, L., Burlingame, G. M., Pašalić, A., Duraković, E., ... Pynoos, R. S. (2008). Effectiveness of a school-based group psychotherapy program for warexposed adolescents: A randomized controlled trial. Journal of the American Academy of Child and Adolescent Psychiatry, 47(9), 1048-1062. https://doi.org/10.1097/CHI.0b013e31817eecae.

Liu, M., Wang, L., Shi, Z., Zhang, Z., Zhang, K., \& Shen, J. (2011). Mental health problems among children one-year after Sichuan earthquake in China: A follow-up study. PLoS ONE, 6(2), 8-13. https://doi.org/10.1371/journal.pone.0014706.

Macksoud, M. S., \& Aber, J. L. (2016). The War Experiences and Psychosocial Development of Children in Lebanon. Wiley on behalf of the Society for Research in Child Development Stabil URL : http://www.jstor.org/stable/1131687, 67(1), 70-88.

Norris, F. H., Byrne, C. M., Diaz, E., Friedman, M. J., Watson, P. J., \& Kaniasty, K. (2002). 60 , 000 Disaster Victims Speak : Part I . An Empirical Review of the Empirical Literature , 65(3), 1981-2001.

Ooi, C. S., Rooney, R. M., Roberts, C., Kane, R. T., Wright, B., \& Chatzisarantis, N. (2016). The efficacy of a group cognitive behavioral therapy for war-affected young migrants living in 
australia: A cluster randomized controlled trial. Frontiers in Psychology, 7(OCT). https://doi. org/10.3389/fpsyg.2016.01641.

Osofsky, H. J., Osofsky, J. D., Kronenberg, M., Brennan, A., \& Hansel, T. C. (2009). Posttraumatic Stress Symptoms in Children After Hurricane Katrina: Predicting the Need for Mental Health Services. American Journal of Orthopsychiatry, 79(2), 212-220. https://doi.org/10.1037/ a0016179.

Popay, J., Baldwin, S., Arai, L., Britten, N., Petticrew, M., Rodgers, M., \& Sowden, A. (2007). Guidance on the conduct of narrative synthesis in systematic reviews: A product from the ESRC Methods Programme. Guidance on the Conduct of Narrative Synthesis in Systematic Reviews: A Product from the ESRC Methods Programme, METHODS BR(Nisan 2006), 13. https://doi. $\operatorname{org} / 10.13140 / 2.1 .1018 .4643$.

President, T., Commission, N. F., \& January, M. H. (2003). New Freedom Commission on Mental Health. Achieving the Promise: Transforming Mental Health Care in America, DHHS Pub. No. SMA-03-3832.

Pynoos, RS. Frederick, C. Nader, K. Arroyo, W. Steinberg, A. Eth, S. Nunez, F. \& Fairbanks, L. (1987), Life threat and posttraumatic stress in school-age children, Archives of General Psychiatry, 44( 12), 1057-1063.

Pynoos, R, Rodriguez, N, Steinberg, A, Stuber, M, Frederick, C. (1998). The University of California at Los Angeles Posttraumatic Stress Disorder Reaction Index (UCLA-PTSD RI) for DSM-IV (Revision 1). Los Angeles, https://scholar.google.co.uk/scholar?hl=en\&q=Pynoos $\% 2 \mathrm{C}+\mathrm{R} . \%$ $2 \mathrm{C}+$ Rodriguez $\% 2 \mathrm{C}+\mathrm{N} . \% 2 \mathrm{C}+$ Steinberg $\% 2 \mathrm{C}+\mathrm{A} . \% 2 \mathrm{C}+\mathrm{Stuber} \% 2 \mathrm{C}+\mathrm{M} . \% 2 \mathrm{C}+\% 26+$ Frederick $\% 2 \mathrm{C}+\mathrm{C} .+\% 281998 \% 29 .+\mathrm{UCLA}+\mathrm{PTSD}+\mathrm{Index}+$ for + DSM-IV.\&btnG $=\&$ as_sdt=1\%2C5\&as $\mathrm{sdtp}=\# 1$ adresinden edinilmiştir.

Raviv, T., \& Jaycox, L. H. (2015). Trauma Exposure Among School-Aged Youth, 7-15.

Reddy, L. A. (2009). School-based prevention and intervention programs for children with emotional disturbance: a review of treatment components and methodology. Psychology in the Schools, 46(2).

Rolfsnes, E. S., \& Idsoe, T. (2011). School-Based Intervention Programs for PTSD Symptoms: A Review and Meta-Analysis. Journal of Traumatic, 24(2), 155-165.

Roussos, A., Goenjian, A., Steinberg, A., Sotiropoulou, C., Kakaki, M., Kabakos, C., ... Manouras, V. (2005). Posttraumatic Stress and Depressive Reactions Among Children and ... The American Journal of Psychiatry, 162(3), 530-537. http:// ezproxy.library.und.edu/login?url=http://search.proquest.com/docview/220485357? accountid $=28267$ adresinden edinilmiştir.

Salloum, A., \& Overstreet, S. (2008). Evaluation of individual and group grief and trauma interventions for children post disaster. Journal of Clinical Child and Adolescent Psychology, 37(3), 495-507. https://doi.org/10.1080/15374410802148194.

Silverman, W. K., \& La Greca, A. M. (2004). Children experiencing disasters: Definitions, reactions, and predictors of outcomes. Helping Children Cope with Disasters and Terrorism., 11-33. https://doi.org/10.1037/10454-001. 
Smith,P. Dyregrov, A. And Yule, W. (2000) Children and war: teaching recovery techniques. Children and War Foundation.

Smith, P., Perrin, S., Dyregrov, A., \& Yule, W. (2003). Principal components analysis of the Impact of Event Scale with children in war, Personality and Individual Differences, 34, 315-322.

Substance Abuse and Mental Health Services Administration. (2014). SAMHSA's concept of trauma and guidance for a trauma-informed approach. HHS Publication No. (SMA) 14-4884, (July), 1-22.

Sullivan, A. L., \& Simonson, G. R. (2016). A Systematic Review of School-Based Social-Emotional Interventions for Refugee and War-Traumatized Youth. Review of Educational Research, 86(2), 503-530. https://doi.org/10.3102/0034654315609419.

Thabet, A. A., Tawahina, A. A., El Sarraj, E., \& Vostanis, P. (2008). Exposure to war trauma and PTSD among parents and children in the Gaza strip. European Child and Adolescent Psychiatry, 17(4), 191-199. https://doi.org/10.1007/s00787-007-0653-9.

Tol, W. A., Komproe, I. H., Jordans, M. J., Vallipuram, A., Sipsma, H., Sivayokan, S., ... \& De Jong, J. T. (2012). Outcomes and moderators of a preventive school based mental health intervention for children affected by war in Sri Lanka: a cluster randomized trial. World Psychiatry, 11(2), 114-122.

UNESCO (2016) Nearly a quarter of the world's children live in conflict or disasterstricken countries https://www.unicef.org/press-releases/nearly-quarter-worldschildren-live-conflict-or-disaster-stricken-countries adresinden edinilmiştir (18 Haziran 2019 tarihinde ulaşıldı).

Weine S, Becker D, McGlashan T, Vojvoda D, Hartman S, Robbins J (1995) Adolescent survivors of 'ethnic cleansing': observations on the first year in America, Journal of the American Academy of Child and Adolescent Psychiatry, 34 , 1153-1159.

Papageorgiou, V., Frangou-Garunovic, A., Iordanidou, R., Yule, W., Smith, P., \& Vostanis, P. (2000). War trauma and psychopathology in Bosnian refugee children. European child \& adolescent psychiatry, 9(2), 84-90. 